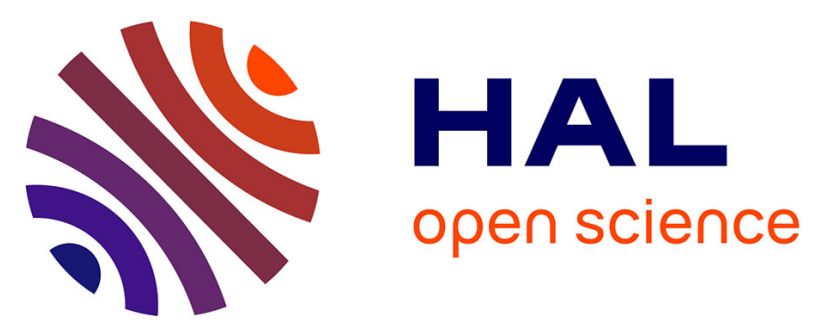

\title{
Experimental Study on the Use of Enhanced Coconut Oil and Paraffin Wax Phase Change Material in Active Heating Using Advanced Modular Prototype
}

Khaireldin Faraj, Mahmoud Khaled, Jalal Faraj, Farouk Hachem, Cathy Castelain

\section{To cite this version:}

Khaireldin Faraj, Mahmoud Khaled, Jalal Faraj, Farouk Hachem, Cathy Castelain. Experimental Study on the Use of Enhanced Coconut Oil and Paraffin Wax Phase Change Material in Active Heating Using Advanced Modular Prototype. Journal of Energy Storage, 2021, 41, pp.102815. 10.1016/j.est.2021.102815 . hal-03291107

\section{HAL Id: hal-03291107 \\ https://hal.science/hal-03291107}

Submitted on 20 Jul 2021

HAL is a multi-disciplinary open access archive for the deposit and dissemination of scientific research documents, whether they are published or not. The documents may come from teaching and research institutions in France or abroad, or from public or private research centers.
L'archive ouverte pluridisciplinaire HAL, est destinée au dépôt et à la diffusion de documents scientifiques de niveau recherche, publiés ou non, émanant des établissements d'enseignement et de recherche français ou étrangers, des laboratoires publics ou privés. 


\title{
Experimental Study on the Use of Enhanced Coconut Oil and Paraffin Wax Phase Change Material in Active Heating Using Advanced Modular Prototype
}

\author{
Khaireldin Faraj ${ }^{1,2}$, Mahmoud Khaled ${ }^{3,4^{*}}$, Jalal Faraj ${ }^{3,5}$, Farouk Hachem ${ }^{2}$, Cathy Castelain ${ }^{1}$ \\ ${ }^{1}$ Laboratory of Thermal Energy of Nantes, LTEN, Polytech' Nantes, University of Nantes, Nantes-France. \\ ${ }^{2}$ Energy and Thermo-Fluid Group, Lebanese International University, LIU, PO Box 146404 Bekaa, Lebanon. \\ ${ }^{3}$ Energy and Thermo-Fluid Group, The International University of Beirut BIU, PO Box 146404 Beirut, Lebanon. \\ ${ }^{4}$ University Paris Diderot, Sorbonne Paris Cite, Interdisciplinary Energy Research Institute (PIERI), Paris, France. \\ ${ }^{5}$ Lebanese university, Faculty of Technology, Saida, Lebanon
}

*In correspondence to: Mahmoud Khaled, International University of Beirut, PO Box 146404, Beirut, Lebanon E-mail : mahmoud.khaled@liu.edu.lb; Phone : 009611706881/2/3/4 ; Fax : 009611306044

\begin{abstract}
The use of phase change materials in buildings as a thermal energy storage system gained the attention of researchers all over the world. In the current study, coconut oil bio-based PCM is macro-encapsulated with enhanced thermal conductivity containers and coupled with hydronic radiant floor heating system. The study follows experimental aspect utilizing two identical small scale modular test prototypes. Investigations are directed toward studying the effect of the active CO-PCM system under different weather conditions, effect of combining active and passive systems, effect of PCM choice/type and effect of PCM location within the active floor, on the thermal and energy storage performances. Results revealed that coupling CO-PCM to active floor, passive wall and passive roof is capable of achieving load shifting and energy savings; and is affected by the control method, weather conditions, electricity tariff policy and PCM position and type. Further discussions, conclusions and perspective recommendations are summarized within the article.
\end{abstract}

\section{Highlights}

- Identical experimental advanced modular prototypes are designed and implemented.

- Macro-encapsulation technique using enhanced thermal conductivity containers.

- Thermal comfort and temperature fluctuations reduction using CO and PW PCMs.

- Load shifting by combined CO-PCM applications leads to possible annual cost saving.

- Positioning CO-PCM plates below heating layer ensued energy saving of $393.5 \mathrm{kWh}$.

Keywords: Phase Change Materials; Modular Prototype; Coconut-oil; Paraffin wax; Radiant Heating System; Thermal Energy Storage.

\section{Introduction}

Within the past few decades, the world has encountered a massive increase in energy consumption accompanied by an increase in $\mathrm{CO}_{2}$ emissions that lead to arising environmental risks. This enormous increase was a consequence to the growth in world's population that stimulated the evolution of economy and energy demand [1]. Buildings proved to be accumulating for the largest energy consumption quantity world-widely, with a percentage ranging between $30-40 \%{ }^{1}$ [2-5], that is expected to rise up by 2050 reaching $50 \%$ [6]. The majority of energy consumed within the building sector is directed toward heating and cooling systems. For instance,

\footnotetext{
${ }^{1}$ The percentages differs in regions and countries: 40\% in Europe [73][74], 33\% in China [75], 40\% in U.S. [76] and 28\% in Tunisia
} [77]. 


\section{Abbreviations}

$\begin{array}{llll}\text { PCM } & \text { Phase change material } & \text { SAH } & \text { Solar air heater } \\ \text { TES } & \text { Thermal energy storage } & \text { RC } & \text { Radiative cooling } \\ \text { LHS } & \text { Latent heat storage } & \text { RHS } & \text { Radiant heating system } \\ \text { SHS } & \text { Sensible heat storage } & \text { EPS } & \text { Expanded polystyrene Foam } \\ \text { NZEB } & \text { Net zero energy building } & \text { XPS } & \text { Extruded polystyrene Foam } \\ \text { TW } & \text { Trombe wall } & \text { SWHS } & \text { Solar water heating system } \\ \text { TABS } & \text { Thermally activated building structure } & \text { HVAC } & \text { Heating, ventilating and air conditioning } \\ \text { HAR } & \text { Heat accumulator } & \text { PCMW } & \text { PCM wallboard } \\ \text { EG } & \text { Expanded Graphite } & \text { EP } & \text { Expanded Perlite } \\ \text { SAT-FA } & \text { Sodium acetate trihydrate-formamide } & \text { ERFHS } & \text { Electric radiant floor heating system } \\ & & \text { HRFHS } & \text { Hydronic radiant floor heating system } \\ & & \\ \text { Units and symbols } & & \\ \text { Temperature } & T\left({ }^{\circ} \mathrm{C}\right) & \text { Conductivity } & k(W / \mathrm{m} . K) \\ \text { Enthalpy } & h(\mathrm{~kJ} / \mathrm{kg}) & \text { Specific Heat } & C p(\mathrm{~kJ} / \mathrm{kg} . \mathrm{K}) \\ \text { Volume } & V\left(\mathrm{~m}^{3}\right) & \text { Area } & A\left(\mathrm{~m}^{2}\right)\end{array}$

according to U.S. Energy Information Administration space heating and air conditioning accounts for $48 \%$ of overall energy consumption in residential site [7]; and according to ministry of electricity and water in Kuwait, cooling systems in buildings account for $70 \%$ of electricity produced in power plants [8]. For that, it is essential to develop new materials and adapt buildings and their heating/cooling systems to align with the requirements needed for energy conservation enhancement and sustainability in constructions [9].

Thermal energy storage (TES) in buildings, with its three distinctive forms: latent, sensible and thermochemical, became a key element in the process of building adaptation toward Sustainability and Green Buildings. Phase change material latent heat thermal energy storage (PCM-LHTES) proved to be a promising technique in storing energy, filling the gap between supply and demand, due to its high latent heat over narrow temperature ranges $[10,11]$. With their favorable properties, PCMs are capable of increasing the buildings thermal mass, performing load shifting, enhancing occupants thermal comfort and increasing overall building energy efficiency. Furthermore, proper use of PCM applications in buildings contributes to the international trend toward implementing Net Zero Energy Buildings (NZEB) building policies (which is to be implemented by 2030 in U.S. [12]). Also, motivating people towards contributing in PCM energy storage systems utilization requires social awareness [13]. Researches focused on the use of PCM in buildings contained several applications that are categorized as Passive PCM applications or Active PCM applications. PCMs are used passively in building envelopes as: walls [14-16], Trombe walls [17], solar façades [18,19], roofs [8], floors , suspended ceilings [20], windows [21], decorative elements, furniture and textiles [22-24], and passive heat exchanger components; or actively being coupled to: radiant heating systems (RHS) [25-27], solar water heating systems (SWHS) [28], radiative cooling (RC) [29], thermally activated building structures (TABS), solar air heater (SAH) [30-32], heating, ventilating and air conditioning (HVAC), geo-cooling [2], activated TWs and activated solar façades. Any combination of the aforementioned PCM-LHTES system applications yields a particular important study as mentioned in previous works [33,34].

Between all heating applications, radiant underfloor heating/cooling coupled with PCM has promising performance. Radiant heating systems can be either hydronic heating systems utilizing a working fluid and can be coupled to SWHS, or an electrical radiant mat system which rely on the advantage of load shifting enabled by PCMs. Recent studies related to the use of PCM coupled to radiant heating system in buildings (forming an active application) and the adapted systems as well as hybrid studies are reviewed thoroughly.

Several research articles were conducted and targeted towards investigating the performance of underfloor radiant systems coupled with PCM. Lin et al. [35] investigated the effect of integrating paraffin-based SSPCM 
with electric radiant heating system in Tsinghua, Beijing, China. A large-scale test room was constructed $(3 \times$ $2 \times 2 \mathrm{~m}^{3}$ ) with the floor containing electric heater above which lies the PCM. Results showed that more than $50 \%$ of electric load required for sustaining thermal comfort was shifted to off-peak periods which allows economic savings due to different electricity Tariffs between day and night [36]. Huang et al. [37] focused on testing a retrofit integrated with a SWHS coupled to floor capillary tubes under which lies Macro-packs filled with Capric acid PCM and compared by a conventional room in the cold climate of Shenyang, Liaoning, China. Results revealed that PCM is able to supply the room with energy equivalent to $47.7 \%$ of energy supplied by the solar system for $16 \mathrm{hrs}$. Cheng et al. [38] tested the effectiveness of thermal conductivities of SSPCM integrated with ERFHS as retrofitting in a conventional room $\left(4 \times 3 \times 3 \mathrm{~m}^{3}\right)$ located at Yangtze, Anhui, China. Results were promising reflecting that the enhancement in thermal conductivity of PCM promotes the heating system energy efficiency as the thermal conductivity is below $1 \mathrm{~W} / \mathrm{m} . \mathrm{K}$. Zhou and He [39] performed a comparative experimental study on the performance of HFRHS coupled with storage materials (PCM-LHTES and Sand-SHS) utilizing different pipe types (regular PE coils and capillary mat). Results proved that the use of capillary mat is more beneficial compared to PE coils during the charging phase; And, PCM is favorable over sand during discharging process (pumping-off period) with longer duration by 2 times of heat release. A numerical study by Zhou et al. [40] covered the integration of shape-stabilized PCM boards with active heating/cooling pipes for side-wall cooling and underfloor heating. Based on their results, it was depicted that an annual heating energy consumption reduction of $16.2 \%$ is achieved. Devaux and Farid [27] compared the thermal performance of two different PCM types incorporated in walls, ceilings and in-combination with underfloor heating system. Results showed that the use of PCM enhances thermal comfort and permits successive load shifting and energy consumption reduction contributing an energy and cost savings of $32 \%$ and $42 \%$, respectively.

$\mathrm{Lu}$ et al. [41] introduced a solar water heating system and coupled it to PCM floor. The PCM was macroencapsulated at the circumference of the heating pipes passing the floor. The authors performed experimental analysis via two identical large-scale prototypes, and numerical analysis using TRNSYS software and results were promising. Experimental results revealed that the fluctuations in indoor temperature were reduced in the PCM room compared to control room, with a $5.87 \%$ reduction in energy consumption if the room is to be maintained at $20^{\circ} \mathrm{C}$. Garg et al. [42] designed and implemented a PCM-based heat exchanger placed in the roof of a smallscale test chamber for heat gain reduction in summer conditions of Mumbai, India. Results showed that a reduction of $50 \%$ in heat gain from the roof, and more than $6{ }^{\circ} \mathrm{C}$ in the mean air temperature were obtained by the PCM heat exchanger. The concept of capillary tubes embedded in PCM as an active system was studied by Jobli et al. [43]. $140 \mathrm{~m}$ long plastic capillaries were embedded in PCM of the ceiling of a test chamber $\left(1.2 \times 1.3 \times 2 \mathrm{~m}^{3}\right)$. A numerical model was validated with the obtained experimental results to show that the robustness of the model is fulfilled when the volumetric flow rate of the working fluid (water) exceeds $800 \mathrm{ml} / \mathrm{min}$ while correction factors are addressed in the reverse case.

The choice of PCM is essential in any application. Fang et al. [44] prepared a novel shape-stabilized PCM composed of sodium acetate trihydrate-formamide (SAT-FA) and expanded graphite (EG) as supporting material, for the use with electric radiant floor heating systems (ERFHS). The prepared PCM plates were used in an insulated small-scale simulation test facility $\left(1.15 \times 1.15 \times 1.3 \mathrm{~m}^{3}\right)$ equipped with ERFHS. Results showed that the thermal performance of the system with PCM was enhanced were thermal comfort was increased as the temperature fluctuations in vertical indoor environment decreased. In a comparative study directed toward investigating the effect of combining active and passive PCM applications, Kong et al. [5] managed to introduce a novel system composed of PCM wallboards (passive) prepared from paraffin and EP, and a heat accumulator (HAR) filled with PCM coupled to a solar heating system used as a radiating wall. Two identical test cubicles of $1 \mathrm{~m}$ edge size comprising a window were prepared and tested under different stages. Results revealed that PCMW enhanced the thermal inertia of the test cubicle and that the functioning duration of the solar heating system was increased by means of HAR filled with Paraffin PCM; And the combination of both systems enhanced the thermal comfort and building thermal efficiency for the cubicle.

Combination of different PCM applications in buildings yields significant enhancement in building thermal performance. Several studies focused on testing the effect of integrating two different PCM applications. Lu et al. [45] studied the effect of combining hydronic radiant floor heating system (HRFHS) as active application with a Trombe wall passive system. It was depicted that a positive difference of $7.5^{\circ} \mathrm{C}$ in the average indoor temperature 
between PCM room and reference room was achieved. Also, it was found that an average energy-saving rate of $54.27 \%$ was achieved by the PCM room compared to the reference room. Zhu and Yang [46] validated a numerical model through an experimental study focusing on the thermal performance of a PCM building envelope embedded with radiant cooling pipes. The simulation covered the effect of pipe spacing and PCM thickness as well as orientation of the embedded wall. It was proved that pipe embedded PCM envelope is effective in terms of thermal comfort enhancement and energy saving during the heating season.

A numerical study executed by Plytaria et al. [47] focused on the simulation of solar cooling radiant walls coupled with PCM using TRNSYS software for a $100 \mathrm{~m}^{2}$ area building. Results revealed that the optimum location of PCM is in the south wall with a reduction of auxiliary energy of $30 \%$. In another numerical study with the same building dimensions, Plytaria et al. [48] managed to investigate and optimize the performance of underfloor solar assisted heating system integrated with PCM. Using TRNSYS simulation tool authors proved that the use of BioPCM Q29 as Macro-encapsulated PCM placed under the floor heating tubes reduces the auxiliary energy load by $65 \%$, and the rise of indoor temperature reached $0.8{ }^{\circ} \mathrm{C}$.

Sun et al. [49] prepared three identical laboratory small-scale test facilities to test the thermal performance of HRFHS coupled with double-layer PCM utilizing different inorganic PCMs namely: $\mathrm{Na}_{2} \mathrm{HPO}_{4} \cdot 12 \mathrm{H}_{2} \mathrm{O}$ $\left(\mathrm{T}_{\mathrm{m}}=31.3^{\circ} \mathrm{C}\right)$ and $\mathrm{CaCl}_{2} \cdot 6 \mathrm{H}_{2} \mathrm{O}\left(\mathrm{T}_{\mathrm{m}}=20.2^{\circ} \mathrm{C}\right)$. Three identical test facilities $\left(0.44 \times 0.44 \times 0.57 \mathrm{~m}^{3}\right)$ were constructed and equipped as follows: reference cell containing pebbles (8-12 mm diameter), PCM cell 1 having TM/EG composite PCM at the bottom while DHPD-SSP/EG PCM above, and PCM cell 2 containing PCMs in reverse order. The cells were placed in an artificial climate chamber simulating summer and winter conditions. Results showed that for winter and summer climates, thermal comfort duration offered by the PCM was 2.2 and 1.7 times that in the reference room, respectively, taking into account reversing the positions of the double layered PCMs (test cell 3). Lee et al. [12] performed an experimental study on the performance of high-tech HRFHS with PCM. The study involved two main aspects: thermal behavior and stress analysis. Four different systems are tested based on the amount of SSPCM coupled with the HFRHS as follows: $1000 \mathrm{~g}, 2000 \mathrm{~g}, 4000 \mathrm{~g}$ and $8000 \mathrm{~g}$ of SSPCM per unit area referred as A_10, A_20, A_40 and A_80. Results showed that HFRHS coupled with PCM could store more heat as the amount of SSPCM increases however, the compressive strength that the floor can withstand decreases.

A tabulated summary for the aforementioned studies reviewed in the literature, for direct comparison, is presented in Table 1. Also, the used PCMs in respective studies and their thermo-physical properties are presented and summarized in Table 2.

The above mentioned literature studies, presented in section 1.1, show that most previous research focused on studying the effect of using one type of PCM incorporated with a single active radiant PCM application. Few are the studies focusing on combining active and passive systems. Also, it is found that PCM incorporation methods are directed toward enhancing the thermal conductivity that PCM lack. Parametric analysis is done numerically with validation against reduced-scale prototypes. Also, it is found that plenty of studies utilized a single test facility instead of two thus lacking simultaneous experimental investigation. Some prototypes are far from simulating real case where the sizes and features are inconvenient. Besides, plenty of experiments were done in artificial controlled environments and few are the tests that covers variable real weather conditions. Therefore, the aim of this study is to perform parametric analysis to investigate the effect of integrating PCM as LHTES with HRFHS (active application) and building envelope (passive application) using sustainable enhanced macroencapsulated PCM plates containing coconut oil and paraffin wax. Two advanced modular prototypes are used in the study with conventional enhanced insulation and features. The study is terminated with relevant conclusions and future recommendations. 
Table 1 Summary of literature studies for active PCM radiant heating applications in buildings.

\begin{tabular}{|c|c|c|c|c|c|c|c|}
\hline Author & Year & $\begin{array}{l}\text { Test } \\
\text { methodology }\end{array}$ & Prototype/software & Climate & Used PCM & $\begin{array}{l}\text { PCM-LHTES } \\
\text { technique/system }\end{array}$ & Key results \\
\hline $\begin{array}{l}\text { Kong et } \\
\text { al. [5] }\end{array}$ & 2017 & Experimental & $\begin{array}{l}\text { Two identical small- } \\
\text { scale test cubes } \\
\left(1 \times 1 \times 1 \mathrm{~m}^{3}\right)\end{array}$ & Tianjin, China & $\begin{array}{l}\text { Paraffin-based } \\
\text { PCM }\end{array}$ & $\begin{array}{l}\text { Combination of passive } \\
\text { PCMW and active solar } \\
\text { water heater coupled to } \\
\text { HAR filled with PCM }\end{array}$ & $\begin{array}{l}\text { - PCMW enhanced the thermal inertia of the envelope. } \\
\text { - Enhancement in thermal performance, indoor thermal comfort, and } \\
\text { building energy efficiency by combining active HAR with PCM and } \\
\text { passive PCMW. }\end{array}$ \\
\hline $\begin{array}{l}\text { Lu et al. } \\
\text { [41] }\end{array}$ & 2017 & $\begin{array}{l}\text { Experimental } \\
\text { and Numerical }\end{array}$ & $\begin{array}{l}\text { Two identical large- } \\
\text { scale test rooms } \\
\text { / TRNSYS }\end{array}$ & $\begin{array}{l}\text { Ninghe, } \\
\text { Tianjin, China }\end{array}$ & $\begin{array}{l}\text { CA-HA (capric } \\
\text { acid with } \\
\text { hexadeycl } \\
\text { alcohol) }\end{array}$ & $\begin{array}{l}\text { PCM floor coupled with } \\
\text { solar water heating system }\end{array}$ & $\begin{array}{l}\text { - Indoor temperature fluctuations decreased in PCM room compared } \\
\text { to reference. } \\
\text { - Energy consumption saving of } 5.87 \% \text { was achieved in PCM room } \\
\text { if indoor temperature was maintained at } 20^{\circ} \mathrm{C} \text {. }\end{array}$ \\
\hline $\begin{array}{l}\text { Garg et al. } \\
\text { [42] }\end{array}$ & 2018 & $\begin{array}{l}\text { Experimental } \\
\text { and Numerical }\end{array}$ & $\begin{array}{l}\text { Small-scale test } \\
\text { chamber }\end{array}$ & $\begin{array}{l}\text { Mumbai, } \\
\text { India }\end{array}$ & $\begin{array}{l}\text { HS24 } \\
\text { (In-organic } \\
\text { chemical } \\
\text { compound) }\end{array}$ & $\begin{array}{l}\text { Radiant heat exchanger } \\
\text { with PCM in the roof }\end{array}$ & $\begin{array}{l}\text { - PCM based heat exchanger decreases heat gain to test chamber by } \\
50 \% \text { and indoor temperature by more than } 6^{\circ} \mathrm{C} \text {. }\end{array}$ \\
\hline $\begin{array}{l}\text { Lu et al. } \\
{[45]}\end{array}$ & 2018 & Experimental & $\begin{array}{l}\text { Two identical large- } \\
\text { scale test rooms } \\
\left(2 \times 2 \times 2.5 \mathrm{~m}^{3}\right)\end{array}$ & Tianjin, China & $\begin{array}{l}\text { Paraffin-based } \\
\text { PCM }\end{array}$ & $\begin{array}{l}\text { Combination of passive } \\
\text { Trombe wall and active } \\
\text { HRFHS with PCM }\end{array}$ & $\begin{array}{l}\text { - average indoor temperature is higher in the } \mathrm{PCM} \text { room by } 7.15^{\circ} \mathrm{C} \\
\text { is passive stage. } \\
-54.27 \% \text { average energy-saving rate achieved by } \mathrm{PCM} \text { room } \\
\text { compared to reference room. }\end{array}$ \\
\hline $\begin{array}{l}\text { Fang et al. } \\
\text { [44] }\end{array}$ & 2019 & Experimental & $\begin{array}{l}\text { small-scale test room } \\
(1.15 \times 1.15 \times \\
\left.1.3 \mathrm{~m}^{3}\right)\end{array}$ & - & $\begin{array}{l}\text { Salt-hydrate- } \\
\text { based Eutectic } \\
\text { PCM }\end{array}$ & $\begin{array}{l}\text { Underfloor electrical } \\
\text { heating with PCM }\end{array}$ & $\begin{array}{l}\text { - Vertical temperature fluctuations decreased with the presence of } \\
\text { PCM, with an increase in thermal comfort time. }\end{array}$ \\
\hline $\begin{array}{l}\text { Jobli et al. } \\
\text { [43] }\end{array}$ & 2019 & $\begin{array}{l}\text { Experimental } \\
\text { and Numerical }\end{array}$ & $\begin{array}{l}\text { Laboratory reduced- } \\
\text { scale prototype }\end{array}$ & $\begin{array}{l}\text { Laboratory } \\
\text { environment }\end{array}$ & $\begin{array}{l}\text { Paraffin-based } \\
\text { PCM }\end{array}$ & $\begin{array}{l}\text { Hybrid capillary tube } \\
\text { PCM wall and ceiling }\end{array}$ & $\begin{array}{l}\text { - Experimental and numerical results agree when the flow rate in the } \\
\text { capillary tubes exceeds } 800 \mathrm{ml} / \mathrm{min} \text {. Otherwise, correction factors } \\
\text { are introduced. }\end{array}$ \\
\hline $\begin{array}{l}\text { Faraj et al. } \\
\quad[26]\end{array}$ & 2019 & Experimental & $\begin{array}{l}\text { small-scale test house } \\
(1.18 \times 1.18 \times \\
\left.1.21 \mathrm{~m}^{3}\right)\end{array}$ & $\begin{array}{l}\text { Agricultural } \\
\text { Refrigerator } \\
\left(0^{\circ} \mathrm{C} \text { to } 5^{\circ} \mathrm{C}\right)\end{array}$ & $\begin{array}{l}\text { Bio-based PCM } \\
\text { (Coconut oil) }\end{array}$ & $\begin{array}{l}\text { Macro-encapsulated PCM } \\
\text { plates coupled with } \\
\text { underfloor electric heating }\end{array}$ & $\begin{array}{l}\text { - CO-PCM permitted successful load shifting. } \\
\text { - Cost saving of } \$ 98 \text { per year was achieved by integrating CO-PCM. }\end{array}$ \\
\hline $\begin{array}{l}\text { Plytaria et } \\
\text { al. [48] }\end{array}$ & 2019 & Numerical & $\begin{array}{l}\text { TRANSYS } 17(10 \times \\
\left.10 \times 3 \mathrm{~m}^{3}\right)\end{array}$ & $\begin{array}{l}\text { Athens, } \\
\text { Greece }\end{array}$ & BioPCM Q29M91 & $\begin{array}{l}\text { PCM integrated in solar } \\
\text { assisted HFRHS }\end{array}$ & $\begin{array}{l}\text { - Reduction of } 65 \% \text { in auxiliary load is acjived for PCM layer under } \\
\text { the underfloor heating pipes. } \\
\text { - Increase of } 0.8^{\circ} \mathrm{C} \text { in the indoor temperature. }\end{array}$ \\
\hline $\begin{array}{l}\text { Sun et al. } \\
\text { [49] }\end{array}$ & 2020 & Experimental & $\begin{array}{l}\text { Three identical test } \\
\text { cells }(0.44 \times 0.44 \times \\
\left.0.57 \mathrm{~m}^{3}\right)\end{array}$ & $\begin{array}{l}\text { Artificial } \\
\text { climate } \\
\text { chamber }\end{array}$ & $\begin{array}{l}\text { Double-layer of } \\
\text { hydrate salt-based } \\
\quad \text { PCMs }\end{array}$ & $\begin{array}{l}\text { PCM coupled to floor } \\
\text { radiant system }\end{array}$ & $\begin{array}{l}\text { - In winter climate, PCM-1 ensures thermal comfort duration } 2.2 \\
\text { times that in reference cell. } \\
\text { - In summer climate, PCM-2 ensures thermal comfort duration } 1.7 \\
\text { times that in reference cell. }\end{array}$ \\
\hline $\begin{array}{l}\text { Lee et al. } \\
\quad[12]\end{array}$ & 2020 & Experimental & $\begin{array}{l}\text { Thermal room }(0.5 \times \\
\left.0.5 \times 1.8 \mathrm{~m}^{3}\right)\end{array}$ & $\begin{array}{l}\text { Laboratory } \\
\text { controlled } \\
\text { temperature }\end{array}$ & $\begin{array}{l}\text { n-Octadecane } \\
\text { with } \mathrm{xGnP}\end{array}$ & PCM coupled to HFRHS & $\begin{array}{l}\text { - Amount of PCM added in the manufacturing process of SSPCM is } \\
\text { important regarding thermal performance and stress analysis. }\end{array}$ \\
\hline
\end{tabular}


Table 2 Thermo-physical properties of key PCMs used in studied literature and coupled (or designed for the usage) with radiant heating applications for buildings

\begin{tabular}{|c|c|c|c|c|c|c|c|c|c|}
\hline PCM used & Type & $\begin{array}{l}\text { Synthetic/ } \\
\text { commercial }\end{array}$ & Application & $\begin{array}{l}\text { Incorporation } \\
\text { method }\end{array}$ & $\begin{array}{l}\text { Melting } \\
\text { temperature }\end{array}$ & Latent heat & $\begin{array}{l}\text { Thermal } \\
\text { conductivity }\end{array}$ & Specific heat & Ref. \\
\hline $\begin{array}{c}\text { Paraffin } 75 \mathrm{wt} \%+ \\
\text { Polyethylene } 25 \\
\text { wt } \%\end{array}$ & $\begin{array}{l}\text { Paraffin-based } \\
\text { PCM }\end{array}$ & Synthetic & $\begin{array}{l}\text { Underfloor radiant } \\
\text { heating system with } \\
\text { PCM }\end{array}$ & Shape-stabilization & $52^{\circ} \mathrm{C}$ & $150 \mathrm{~kJ} / \mathrm{kg}$ & $0.15 \mathrm{~W} / \mathrm{m} . \mathrm{K}$ & $2 \mathrm{~kJ} / \mathrm{kg} . \mathrm{K}$ & {$[35]$} \\
\hline $\begin{array}{l}\text { Paraffin (Energain } \\
\text { wallboards) }\end{array}$ & $\begin{array}{l}\text { Paraffin-based } \\
\text { PCM }\end{array}$ & Commercial & $\begin{array}{l}\text { Combining PCM- } \\
\text { ERFHS with PCMW } \\
\text { in walls and ceiling } \\
\text { Combined passive }\end{array}$ & $\begin{array}{c}\text { Micro- } \\
\text { encapsulation }\end{array}$ & $28^{\circ} \mathrm{C}$ & $120 \mathrm{~kJ} / \mathrm{kg}$ & $0.2 \mathrm{~W} / \mathrm{m} . \mathrm{K}$ & $2 \mathrm{~kJ} / \mathrm{kg} . \mathrm{K}$ & {$[27]$} \\
\hline $\begin{array}{l}\text { Paraffin } 60 \mathrm{wt} \%+ \\
\text { EP } 40 \mathrm{wt} \%\end{array}$ & $\begin{array}{l}\text { Paraffin-based } \\
\text { PCM }\end{array}$ & Synthetic & $\begin{array}{l}\text { PCMW with active } \\
\text { solar heated HAR } \\
\text { filled with PCM }\end{array}$ & Shape-stabilization & $25^{\circ} \mathrm{C}$ & $106.2 \mathrm{~kJ} / \mathrm{kg}$ & - & - & {$[5]$} \\
\hline $\begin{array}{c}92 \% \text { SAT-FA }+8 \% \\
\text { EG }\end{array}$ & $\begin{array}{l}\text { Salt-hydrate- } \\
\text { based Eutectic } \\
\text { PCM mixture }\end{array}$ & Synthetic & $\begin{array}{l}\text { Underfloor electrical } \\
\text { heating with PCM }\end{array}$ & Shape-stabilization & $38.54{ }^{\circ} \mathrm{C}$ & $187.6 \mathrm{~kJ} / \mathrm{kg}$ & $3.11 \mathrm{~W} / \mathrm{m} . \mathrm{K}$ & - & {$[44]$} \\
\hline Paraffin & $\begin{array}{c}\text { Paraffin-based } \\
\text { PCM }\end{array}$ & Commercial & $\begin{array}{c}\text { Combined passive TW } \\
\text { with active HRFHS } \\
\text { with PCM }\end{array}$ & $\begin{array}{c}\text { Macro- } \\
\text { encapsulation }\end{array}$ & $35-40^{\circ} \mathrm{C}$ & $\begin{array}{c}73.3-79.6 \\
\mathrm{~kJ} / \mathrm{kg}\end{array}$ & - & - & {$[45]$} \\
\hline RT18HC & $\begin{array}{l}\text { Paraffin-based } \\
\text { PCM }\end{array}$ & Commercial & $\begin{array}{l}\text { Pipe-embedded PCM } \\
\text { cooling wall }\end{array}$ & $\begin{array}{c}\text { Macro- } \\
\text { encapsulated }\end{array}$ & $17-19^{\circ} \mathrm{C}$ & $260 \mathrm{~kJ} / \mathrm{kg}$ & $0.2 \mathrm{~W} / \mathrm{m} . \mathrm{K}$ & $2 \mathrm{~kJ} / \mathrm{kg} . \mathrm{K}$ & {$[46]$} \\
\hline BioPCM Q29M91 & Bio-based PCM & Commercial & $\begin{array}{c}\text { Solar assisted HRFHS } \\
\text { with PCM }\end{array}$ & $\begin{array}{c}\text { Macro- } \\
\text { encapsulated }\end{array}$ & $29^{\circ} \mathrm{C}$ & $\begin{array}{c}210-250 \\
\mathrm{~kJ} / \mathrm{kg}\end{array}$ & $0.15-2.5 \mathrm{~W} / \mathrm{m} . \mathrm{K}$ & $2.2-4.5 \mathrm{~kJ} / \mathrm{kg} . \mathrm{K}$ & {$[48,50]$} \\
\hline $\begin{array}{c}70 \% \text { SAT-urea }+ \\
30 \% \text { fumed silica } \\
\mathrm{SiO}_{2}\end{array}$ & $\begin{array}{l}\text { Non-eutectic } \\
\text { PCM mixture }\end{array}$ & Synthetic & $\begin{array}{l}\text { Underfloor radiant } \\
\text { heating system with } \\
\text { PCM }\end{array}$ & Shape-stabilization & $35.75^{\circ} \mathrm{C}$ & $151.6 \mathrm{~kJ} / \mathrm{kg}$ & - & - & {$[51]$} \\
\hline $\begin{array}{c}75 \% \\
\mathrm{Na}_{2} \mathrm{HPO}_{4} \cdot 12 \mathrm{H}_{2} \mathrm{O}+ \\
25 \% \mathrm{EG}\end{array}$ & $\begin{array}{l}\text { Salt-hydrate- } \\
\text { based PCM }\end{array}$ & Synthetic & HFRHS with PCM & Shape-stabilization & $31.3^{\circ} \mathrm{C}$ & $169.4 \mathrm{~kJ} / \mathrm{kg}$ & - & - & [49] \\
\hline $\begin{array}{c}\text { n-Octadecane }+ \\
\text { xGnP }\end{array}$ & $\begin{array}{l}\text { Paraffin-based } \\
\text { PCM }\end{array}$ & Synthetic & HFRHS with PCM & Shape-stabilization & $28^{\circ} \mathrm{C}$ & $256.5 \mathrm{~kJ} / \mathrm{kg}$ & $0.23 \mathrm{~W} / \mathrm{m} . \mathrm{K}$ & 92 kJ/kg.K & {$[12]$} \\
\hline HS24 (SAVE®) & Inorganic mixture & Commercial & $\begin{array}{l}\text { Roof Radiant cooling } \\
\text { heat exchanger with } \\
\text { PCM }\end{array}$ & $\begin{array}{c}\text { Macro- } \\
\text { encapsulated }\end{array}$ & $23-32{ }^{\circ} \mathrm{C}$ & $199 \mathrm{~kJ} / \mathrm{kg}$ & $1.05 \mathrm{~W} / \mathrm{m} . \mathrm{K}$ & $\begin{array}{l}2.07 \mathrm{~kJ} / \mathrm{kg} . \mathrm{K} \text { (solid) } \\
2.42 \mathrm{~kJ} / \mathrm{kg} . \mathrm{K} \text { (liquid) }\end{array}$ & {$[42]$} \\
\hline $\begin{array}{c}62.5 \% \text { Capric acid } \\
(\mathrm{CA})+37.5 \% \\
\text { hexadecyl alcohol } \\
(\mathrm{HA})\end{array}$ & $\begin{array}{l}\text { Organic-based } \\
\text { mixture }\end{array}$ & Synthetic & $\begin{array}{l}\text { PCM floor coupled } \\
\text { with solar water } \\
\text { heating system }\end{array}$ & $\begin{array}{c}\text { Macro- } \\
\text { encapsulation }\end{array}$ & $19-25^{\circ} \mathrm{C}$ & $\begin{array}{c}266-288 \\
\mathrm{~kJ} / \mathrm{kg}\end{array}$ & $\begin{array}{l}0.116 \mathrm{~W} / \mathrm{m} . \mathrm{K} \\
\text { (solid) } \\
0.148 \mathrm{~W} / \mathrm{m} . \mathrm{K} \\
\text { (liquid) }\end{array}$ & $\begin{array}{c}1.975 \mathrm{~kJ} / \mathrm{kg} . \mathrm{K} \\
\text { (solid) } \\
2.21 \mathrm{~kJ} / \mathrm{kg} . \mathrm{K} \text { (liquid) }\end{array}$ & [41] \\
\hline A23 Plus-ice & Paraffin-based & Commercial & $\begin{array}{l}\text { Hybrid capillary tube } \\
\text { PCM wall and ceiling }\end{array}$ & Micro-encapsulated & $21{ }^{\circ} \mathrm{C}$ & $210 \mathrm{~kJ} / \mathrm{kg}$ & $0.18 \mathrm{~W} / \mathrm{m} . \mathrm{K}$ & $2.22 \mathrm{~kJ} / \mathrm{kg} . \mathrm{K}$ & {$[43]$} \\
\hline
\end{tabular}




\section{Methodology}

The study follows one aspect which is experimental investigation using an advanced modular small-scale prototype. Two identical modular prototypes are designed and implemented where the detailed description is presented in section 2.1. PCM used is macro-encapsulated using enhanced plates and hydronic radiant floor heating is used as the active heating system for the current study. Section 2.2 deals with the measurement tools, reliability tests and uncertainty analysis as well as the control system used for heat load management.
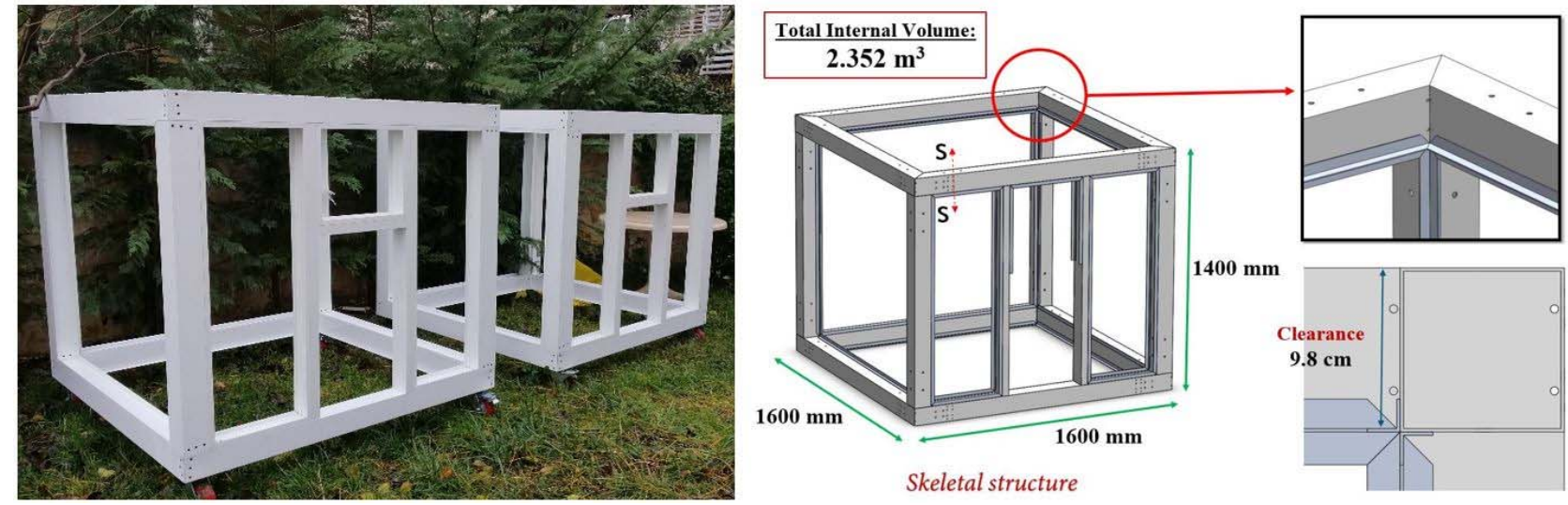

Two small-scale advanced modular test prototypes are designed and implemented such that they follow specified criteria. Firstly, the prototypes are designed to allow several configurations and combinations to be modeled; These are: active, passive, heating, cooling or any combination of these applications. The prototypes are also designed to allow variable PCM types, position and amount, as well as variable envelope partitions thicknesses. Suitable scale, utilization of real features and standardized construction materials are also permitted by the design.

For each prototype, since they are meant to be identical, the following detailed implementation process is followed. Firstly, a skeletal structure made from aluminum squared-hollow beams $\left(\mathrm{Ac}=100 \mathrm{~cm}^{2}\right)$ is assembled as shown in Figure 1Figure 1. L-shape aluminum channels are embedded at the internal edges of the prototypes forming a seat for the envelope side, floor and roof layers. The prototypes are small-scale with the dimensions of $1.6 \mathrm{~m}($ width $) \times 1.6 \mathrm{~m}($ length $) \times 1.4 \mathrm{~m}$ (height) which are nearly 1:8 scaled to a typical Lebanese building room in Bekaa Valley. The internal volume of each prototype is $2.352 \mathrm{~m}^{3}$. Different conventional building material layers are installed in the different sides as illustrated in Figure 2Figure 2. The composition of the walls from internal to external surface is respectively made of: (1) $8 \mathrm{~mm}$ inner wood layer, (2) $30 \mathrm{~mm}$ first XPS insulation layer, (3) $15 \mathrm{~mm}$ Fiber glass insulation layer, (4) $30 \mathrm{~mm}$ second XPS insulation layer, (5) $12 \mathrm{~mm}$ outer wood layer and (6) 4 mm ALUCOBOND® composite finishing layer. Table 3Table 3 summarizes the different dimensions and thermo-physical properties of the different materials for the sides roof and floor composition.

Figure 1 Skeletal structure of the modular prototypes.

Floor layers are installed first, then wall layers and finally the roof. All layers are fastened by relevant screws except the layers of the floor and the west wall. Complete thermal contact for floor layers is dependent on weight, 
while the west wall comprises hold down toggle clamps (shown in Figure 3Figure 3) to facilitate the assembling and resembling of the prototype layers for parametric studies. The test prototypes and compete experimental setup are located at the second floor of a conventional 3-story building in Al-Rafid, Bekaa, Lebanon $\left(33^{\circ} 57 \mathrm{~N}, 35^{\circ} 82\right.$ E). The test facilities are subjected to real weather conditions where the second floor is with no walls (open at all directions). A single-glazing glass door $(0.45 \mathrm{~m} \times 0.70 \mathrm{~m})$ with aluminum frames is installed at the south wall of the prototype, while a double-glazing window $(0.60 \mathrm{~m} \times 0.42 \mathrm{~m})$ with aluminum frames, and air as the filler, is installed at the east wall. Each prototype is mounted on 4 heavy-duty wheels to allow free transportation, with two of the wheels comprising breaks for stability upon testing.

Table 3 Characteristics of possible wall layers used in the initial assembly of the prototype.

\begin{tabular}{|c|c|c|c|c|c|c|}
\hline \multirow{3}{*}{$\mathrm{c}$} & \multicolumn{5}{|c|}{ Characteristics } & \multirow{3}{*}{ Ref. } \\
\hline & \multirow{2}{*}{$\begin{array}{c}\text { Thickness, } \mathrm{t} \\
\mathrm{mm}\end{array}$} & \multirow{2}{*}{$\frac{\text { Density, } \rho}{\mathrm{Kg} / \mathrm{m}^{3}}$} & \multirow{2}{*}{$\begin{array}{l}\text { Specific } \\
\text { Heat, } C_{p} \\
\text { kJ/kg.K }\end{array}$} & \multirow{2}{*}{$\frac{\text { Conductivity, } \lambda}{\text { W/m.K }}$} & \multirow{2}{*}{$\begin{array}{c}\text { Flammability } \\
-\end{array}$} & \\
\hline & & & & & & \\
\hline Aluminum L-channel & 2 & 2698 & 0.921 & 205 & Fire resistant & {$[52,53]$} \\
\hline XPS insulation & 30 & $20.8-43.1$ & - & 0.029 & Fire resistant & {$[54]$} \\
\hline Glass Wool insulation & 15 & $16-40$ & - & $0.035-0.05$ & Fire resistant & {$[55]$} \\
\hline $\begin{array}{c}\text { Wood base layer and } \\
\text { wood cover layer }\end{array}$ & $8-12$ & - & $1.3-2.4$ & $0.41-0.19$ & Flammable & {$[52,56,57]$} \\
\hline $\begin{array}{l}\text { Aluminum composite } \\
\qquad\left(\text { Alucobond }^{\circledR}\right)\end{array}$ & 4 & 0.222 & - & $\begin{array}{c}(U=5.54 \\
\left.W / m^{2} . K\right)\end{array}$ & Fire resistant & {$[58]$} \\
\hline
\end{tabular}
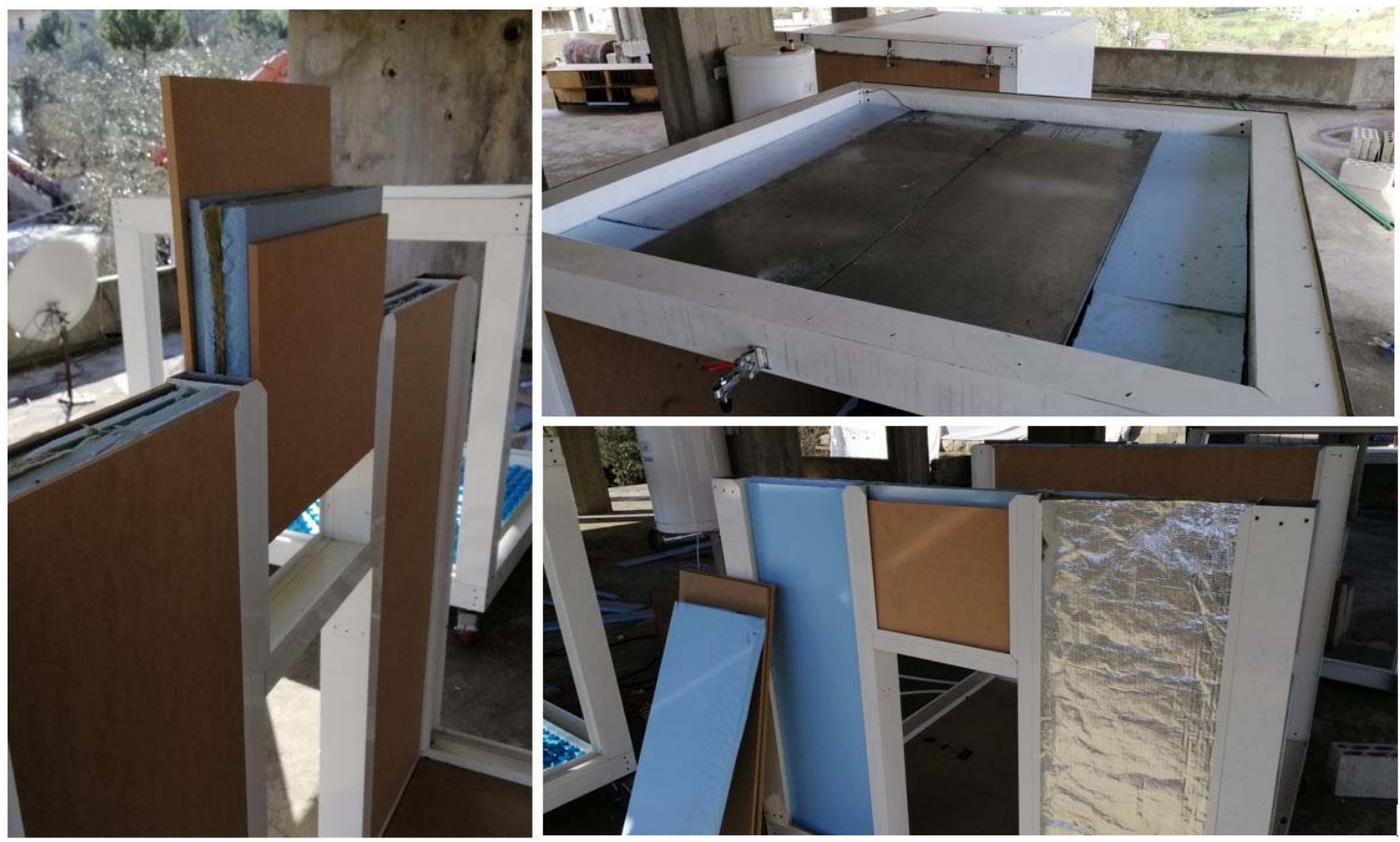

Figure 2 Wall composition showing different layers. 


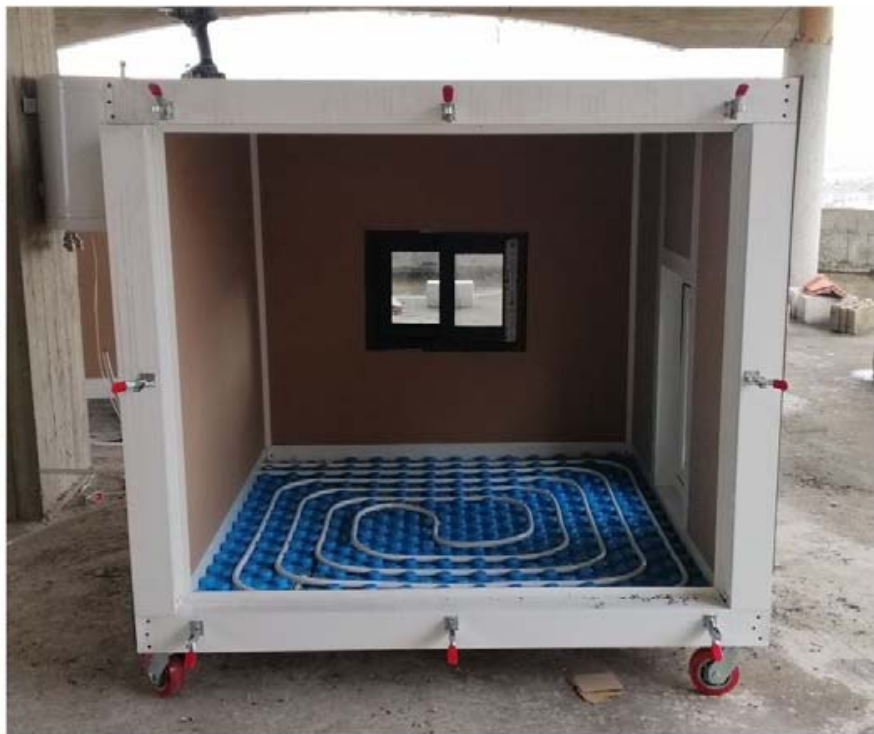

Figure 3 Hold down toggle clamps implemented in the west walls of the prototypes for facilitating assembling and resembling.

The final design of the modular prototype, named "ThermoGreen", and an exploded view of the modeled prototype using SolidWorks software is presented in Figure 4Figure 4. The complete set-up of the two implemented prototypes are illustrated in Figure 5Figure 5.

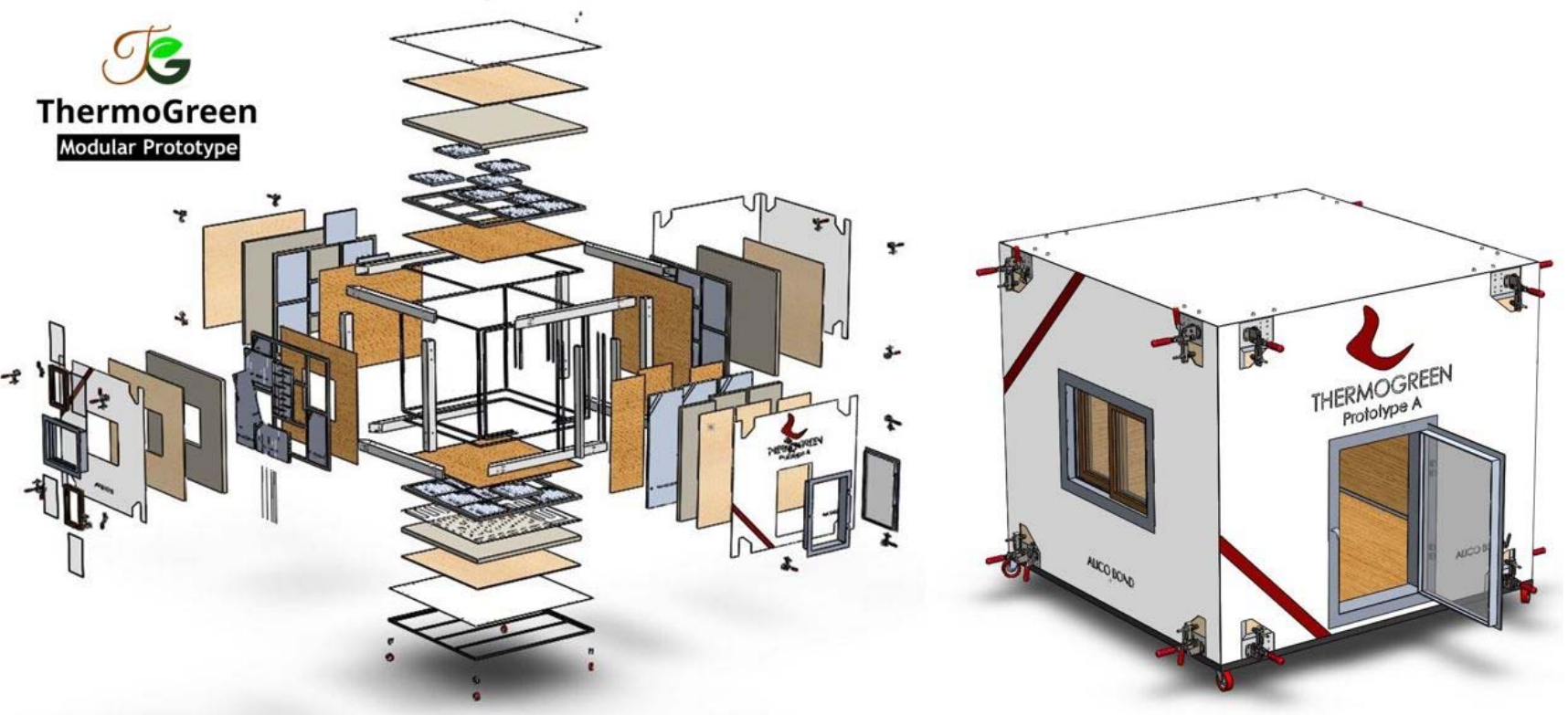

Figure 4 Exploded view and logo of the complete assembly of the modular prototype.

\subsubsection{PCM and Enhanced Encapsulation Plates}

The proper selection of PCM is a critical issue within any study incorporating PCM. The used PCMs in the current study are: Coconut oil (CO) having a melting temperature of $25{ }^{\circ} \mathrm{C}$, and Paraffin wax having a melting temperature of $58-60{ }^{\circ} \mathrm{C}$. The selection was based on using a $\mathrm{PCM}$ that has its melting temperature range compatible with the standard of "Thermal Environmental Conditions for Human Occupancy" (ANSI/ASHRAE standard 55-2013). The standard states that the marginal limits for indoor operative temperature are $20{ }^{\circ} \mathrm{C}$ and 27 
${ }^{\circ} \mathrm{C}$ and the marginal limits for floor surface temperature are $19{ }^{\circ} \mathrm{C}$ and $29{ }^{\circ} \mathrm{C}[44,59]$. The compatibility for $\mathrm{CO}-$ PCM is based on having its melting temperature within the range offered by the aforementioned standard. However, PW-PCM with high melting temperature was selected to check its effectiveness in keeping the heating source at high temperature. Therefore, the location of PCM in the system defines the proper choice of melting range.

The choice of PCM then relies on having maximal heat storage capacity and thermal stability. Environmental concerns are also quite important. $\mathrm{CO}$ and PW have high latent heat $(\sim 103 \mathrm{~kJ} . \mathrm{kg}$ and $189 \mathrm{~kJ} / \mathrm{kg}$ [60], respectively) and are not flammable, but have poor thermal conductivity. Thermo-physical properties of CO-PCM were tested in $\mathrm{TQP}^{2}$ laboratories. The melting temperature of CO-PCM was confirmed to be around $25^{\circ} \mathrm{C}$ and the latent heat was tested using the method of mixtures by applying energy balance as follows:

$$
Q_{\text {loss }}=Q_{\text {gain }}(1)
$$

Which yields:

$$
m_{w} C_{w}\left(T_{i, w}-T_{f, w}\right)=m_{C O} L_{C O}+m_{C O} C_{C O}\left(T_{i, C O}-T_{f, C O}\right)
$$

Where: $m$ is the mass of water/CO (kg), C is the specific heat at constant pressure $(\mathrm{kJ} / \mathrm{kg} . \mathrm{K}), \mathrm{T}_{\mathrm{i}}$ and $\mathrm{T}_{\mathrm{f}}$ are the initial and final temperatures for water $/ \mathrm{CO}\left({ }^{\circ} \mathrm{C}\right)$ and $\mathrm{L}$ is the latent heat of fusion to be determined $(\mathrm{kJ} / \mathrm{kg})$. The method is done by placing a test tube of known mass of solid-state PCM inside a well-insulated water bath of high temperature, where the heat released from the water are gained by the PCM allowing it to melt. Results of the tests are summarized in Table 4Table 4 and compared to reference data from previous researches.

\begin{tabular}{|c|c|c|c|c|c|c|}
\hline CO-PCM & $\operatorname{Tm}\left({ }^{\circ} \mathrm{C}\right)$ & $\mathrm{Cp}(\mathrm{kJ} / \mathrm{kg} . \mathrm{K})$ & $\mathrm{L}_{\mathrm{H}}(\mathrm{kJ} / \mathrm{kg})$ & S.G. & $\mathrm{K}(\mathrm{W} / \mathrm{m} \cdot \mathrm{K})$ & $\begin{array}{c}\text { Fire } \\
\text { retardation }\end{array}$ \\
\hline $\begin{array}{l}\text { Experimental } \\
\text { (TOP) }\end{array}$ & 25 & 2.174 & 102.97 & 0.919 & - & \\
\hline Reference & $\begin{array}{c}22-24[61], 25 \\
{[62], 26.78} \\
{[63]}\end{array}$ & $2.1[64]$ & $\begin{array}{c}103.25[61], \\
70-100[62], \\
110.4[63]\end{array}$ & 0.916 [65] & $\begin{array}{c}0.321[63], 0.5 \\
{[66]}\end{array}$ & $\begin{array}{c}\text { Not } \\
\text { flammable }\end{array}$ \\
\hline
\end{tabular}

Table 4 Thermo-physical properties measured in TQP laboratories.

${ }^{2}$ TQP or Trust for the Quality of Products is a leading firm in material testing that is certified to ISO-9001 and is located in Beirut, Lebanon. 


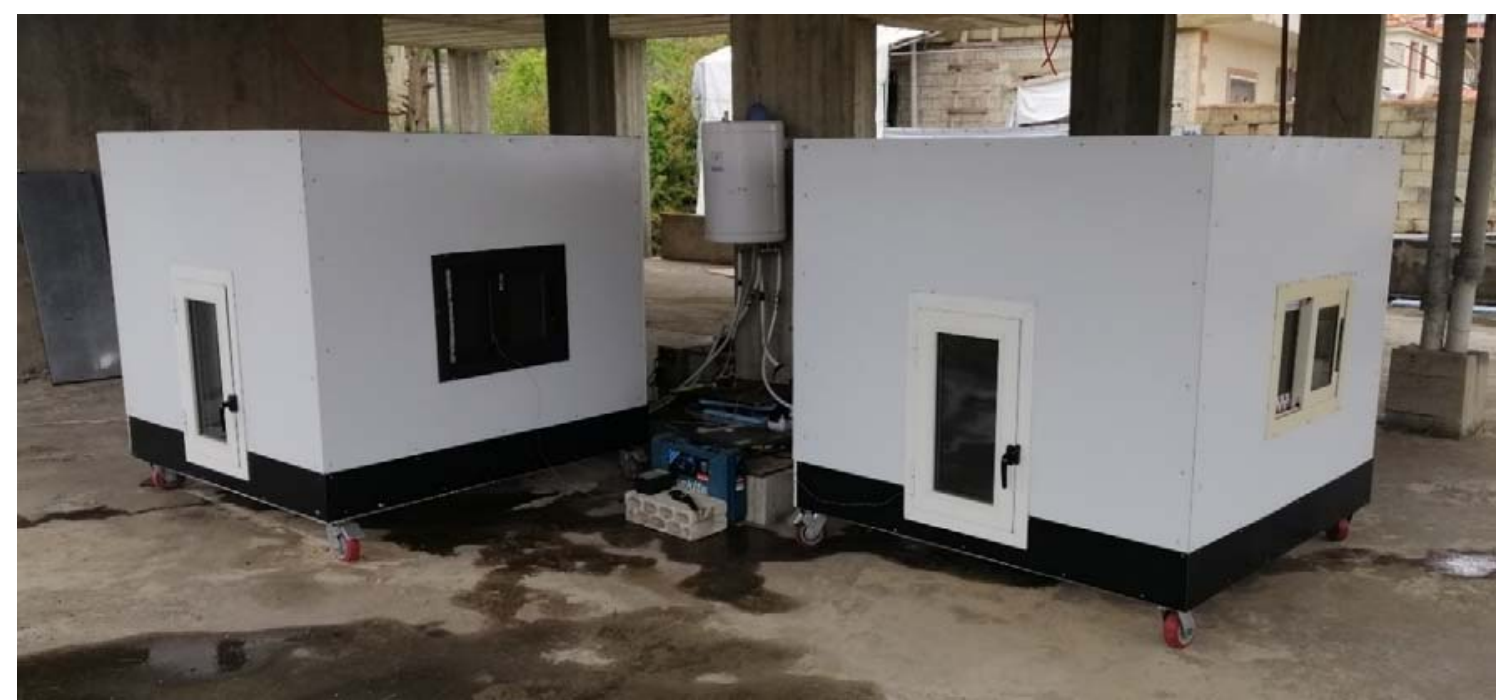

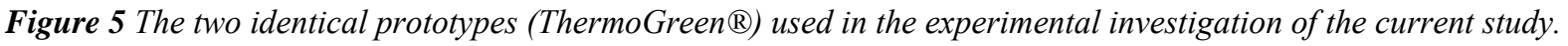
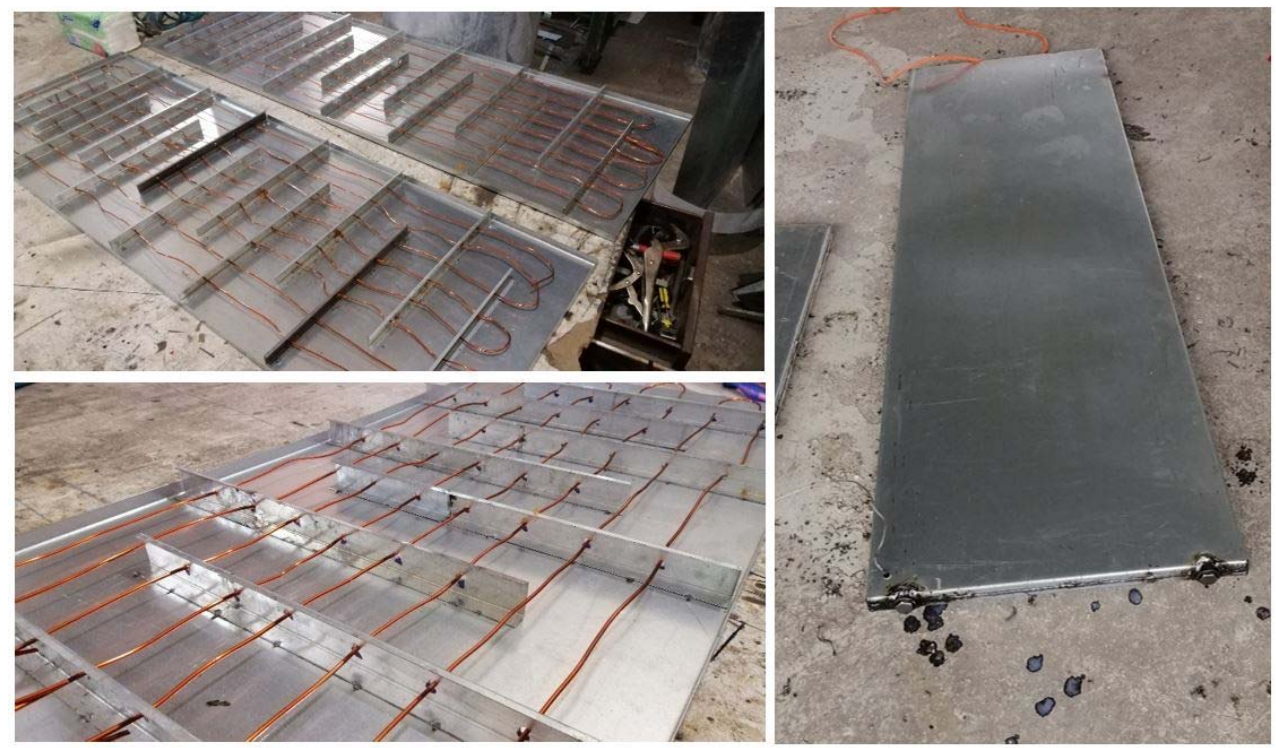

Figure 6 Enhanced PCM macro-containers showing the steel buffers and copper wires.

The incorporation method followed for packing studied PCMs is macro-encapsulation. Galvanized steel is used to fabricate macro-containers that are designed to be $1400 \mathrm{~mm}$ long, $465 \mathrm{~mm}$ wide, and $28 \mathrm{~mm}$ thick. The thickness of the steel boards is $2 \mathrm{~mm}$, which means that $25 \mathrm{~mm}$ thickness for PCM is allowed within the containers. Since thermal conductivity is a critical issue that affects the thermal performance of PCM in buildings, several studies were directed toward enhancing the thermal conductivity.

For the current study, steel buffers $\left(\lambda_{\mathrm{st}}=50.2 \mathrm{~W} / \mathrm{m} . \mathrm{K}\right.$ [52]) are welded inside the containers at a distance of 100 $\mathrm{mm}$ between each two consecutive buffers. The length of each buffer is $350 \mathrm{~mm}$. Also, $3 \mathrm{~mm}$ high-conductivity copper wires $\left(\lambda_{\mathrm{Cu}}=385 \mathrm{~W} / \mathrm{m} . \mathrm{K}\right.$ [52]) are inserted at the mid plane through the aforementioned buffers after being drilled at $50 \mathrm{~mm}$ intervals, forming a net matrix that centralizes PCM and thus enhancing the thermal conductivity of the plate. Figure 6Figure 6 demonstrates the PCM plates showing the formed conductive matrix and the final outcome. The plates are equipped with two drain openings that are capped with screws, and placed at the top edge of the plate to allow filling and draining of liquid PCM. 
It is recommended to use other synthesized bio-PCMs that have favorable thermos-physical properties. Nanoencapsulation of Beeswax through Composite Nanotubes [67,68] and Nano-encapsulation of Palmitic Acid PCM $[69,70]$, are two examples of enhanced PCMs having high melting temperature close to paraffin wax (around $60^{\circ} \mathrm{C}$ ) used in the study but with higher thermal conductivities reaching $2.8 \mathrm{~W} / \mathrm{m} . \mathrm{K}$ and latent heats reaching $115.5 \mathrm{~kJ} / \mathrm{kg}$ for beeswax nanocomposite, and 180 188 kJ/kg for Palmitic acid nanocomposite.

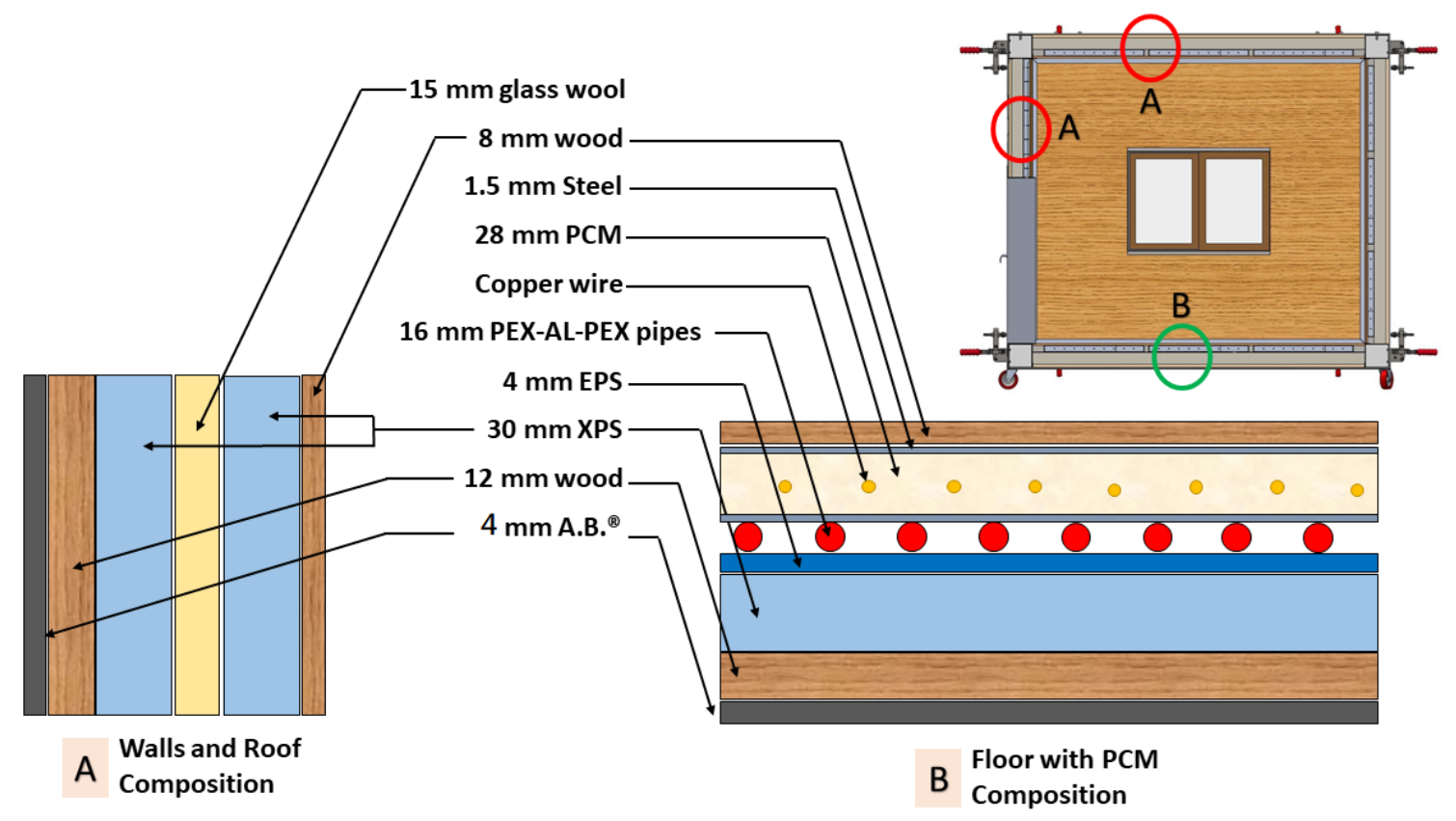

Figure 7 Cross-section of the prototype showing the envelope's material composition.

\subsubsection{Active Hydronic Radiant Floor Heating System}

The used system for fulfilling the heating load is active hydronic floor heating system (HRFHS) using PEXAL-PEX composite pipes of $16 \mathrm{~mm}$ diameter (will be called PEX throughout the context for simplification). These pipes are coextruded crosslinked polyethylene composite pressure tubes that are reinforced by a welded aluminum tube in-between inner and outer layers [71]. The composition of the floor, starting from the outer covering layer at the base, inwardly, is: $12 \mathrm{~mm}$ wood layer, $30 \mathrm{~mm}$ XPS insulation layer, $4 \mathrm{~mm}$ EPS layer with circular pins (16 $\mathrm{mm}$ height) by which the piping net is fixed, $28 \mathrm{~mm}$ CO-PCM enhanced macro-containers and finally an $8 \mathrm{~mm}$ floor covering surface layer of wood. Figure 7Figure 7 illustrates a cross-sectional view for the assembled prototype showing the composition of walls and floor. The layout of the pipe is spiral as shown in Figure 8Figure 8 upon implementation phase and the distance between two adjacent pipes is $10 \mathrm{~cm}$.

The heating tubes are connected to an electrical water heater with a capacity of $50 \mathrm{~L}$ (heater element rated power: $1.5 \mathrm{~kW}$, at $50-60 \mathrm{~Hz}$ ). Figure 9Figure 9 shows a schematic representation for the heating system equipment and connections with measurement, power and control system, for the two prototypes. Heated water is delivered to each prototype via circulating water pump running at a flow rate of 0.15 to $0.17 \mathrm{~kg} / \mathrm{s}$. Technical data for each pump are summarized in Table 5Table 5. At the inlet and exit of each water pump, one-way valve is connected for preventing counter flow and protecting the equipment. After being circulated in the prototypes, water is returned to the heater cold water inlet to be reheated, and thus a closed loop/cycle is formed. The electrical heater has a vent at its top for safety against over pressurization, and contains a thermostat and temperature gauge for temperature regulation at a set point chosen by the operator. The two prototypes are positioned next to each other such that all the faces are subjected to same weather conditions and no face is shaded by another face. 


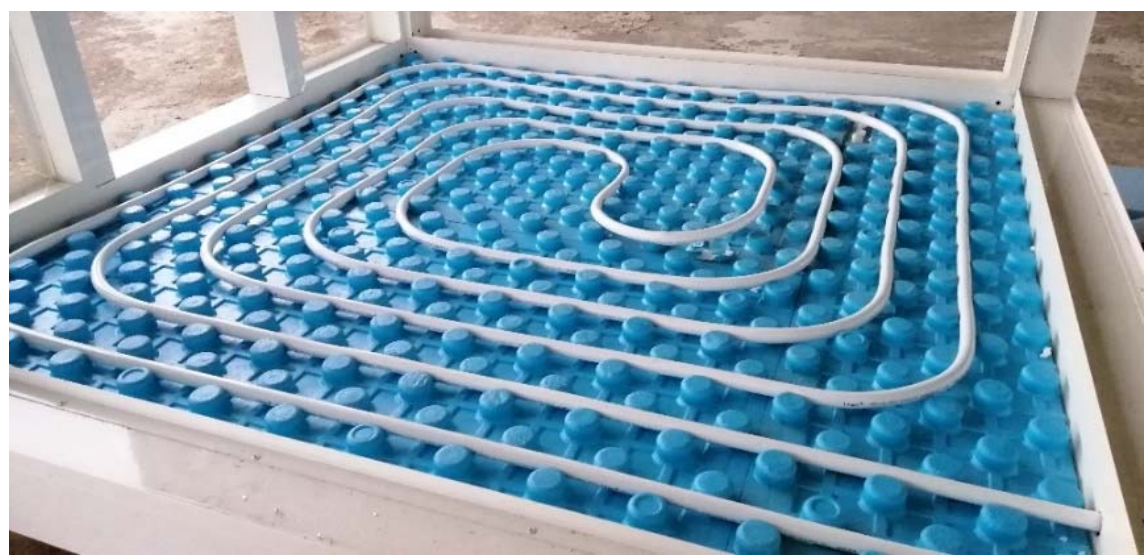

Figure 8 Hydronic pipes configuration at the prototype's floor.

Table 5 Technical data for circulating water pumps used in the study.

\begin{tabular}{c|c|c}
\hline Name & \multicolumn{2}{|c}{$\begin{array}{c}\text { Automatic Boosting Pump } \\
\text { BPS-100 }\end{array}$} \\
\hline Manufacturer & \multicolumn{2}{|c}{ Saad Tahan Co. } \\
\hline Specification & 100 & Unit \\
\hline \hline Power consumption & $220 / 50$ & $\mathrm{~W}$ \\
Power supply & 16 & $\mathrm{~V} / \mathrm{Hz}$ \\
Max. capacity & 12 & $\mathrm{~m}$ \\
Max. head & 4 & $\mathrm{~m}$ \\
Max. suction & 0.5 & inches \\
Pipe diameter & $2850 \quad$ rpm \\
Rotational speed & \multicolumn{2}{c}{ Thermally protected } \\
Protection & \multicolumn{2}{c}{ Certified to ISO9001 } \\
Notes & \multicolumn{2}{c}{}
\end{tabular}




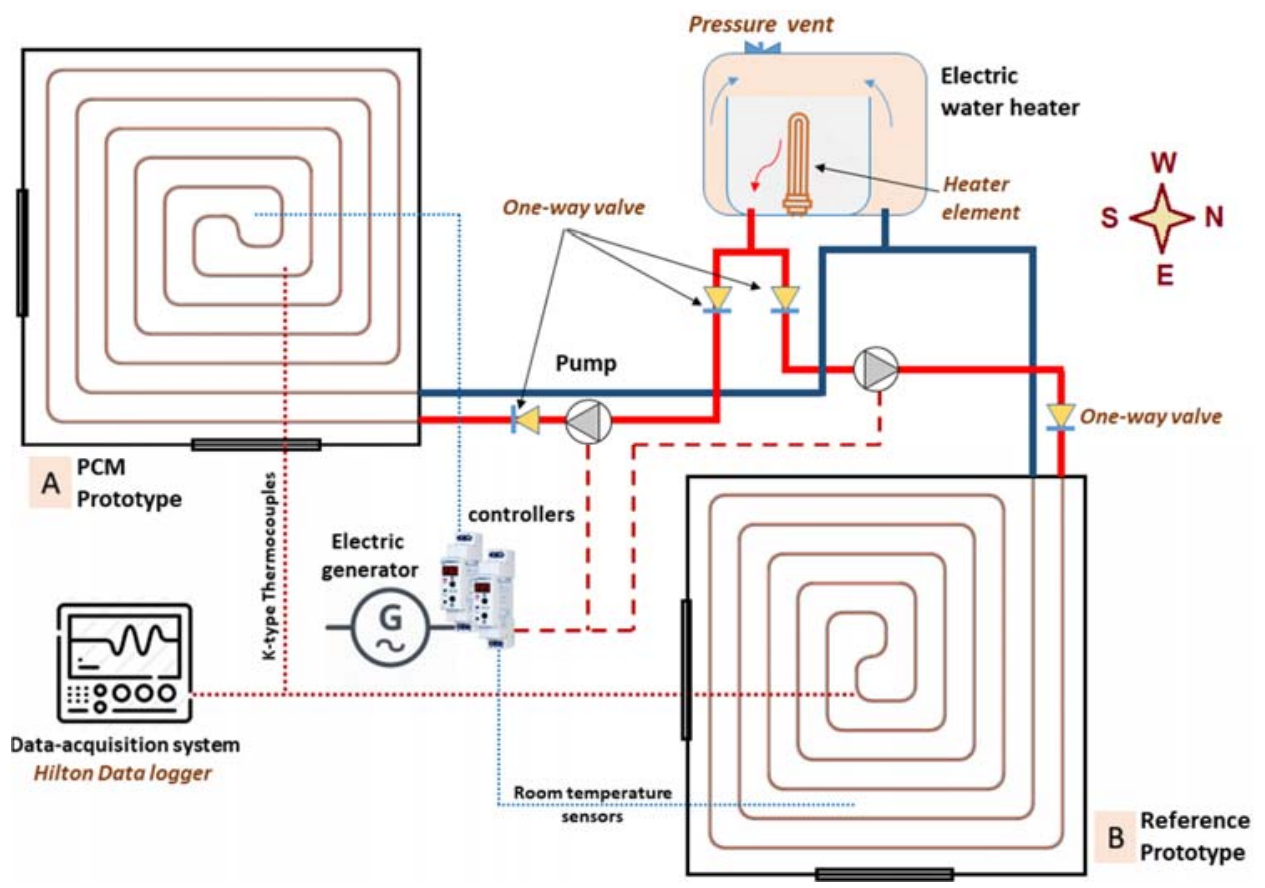

Figure 9 Hydronic radiant heating system implemented in the prototypes and the respective connected measurement and control systems.

\subsection{Measurement Instrumentation and System Control}

\subsubsection{Sensors Used and Reliability Tests}

Measurements are done to test the thermal behavior of the rooms in the presence of PCM. The parameters tested are: (1) temperature $\mathrm{T}$ in ${ }^{\circ} \mathrm{C},(2)$ humidity $\Phi$ as percentage $\%$, (3) solar radiation $\mathrm{G}_{\mathrm{s}}$ in $\mathrm{W} / \mathrm{m}^{2}$ and (4) wind speed $\mathrm{V}_{\mathrm{w}}$ in $\mathrm{m} / \mathrm{s}$. Temperature is the most influencing and critical parameter in the study. For that, 12 K-type thermocouples are used to measure temperatures at different positions within the prototypes with an accuracy of $\pm 1.5^{\circ} \mathrm{C}$ and a resolution of $0.25^{\circ} \mathrm{C}$. Humidity is measured using a humidity sensor; Wind speed is measured using an air-flow anemometer AR $816^{+}$(manufactured by SMART SENSOR $®$ ) with an accuracy of $\pm 5 \%$ and a resolution of $0.1 \mathrm{~m} / \mathrm{s}$; And solar radiation is measured by a solar power meter with $\pm 5 \%$ accuracy and $0.1 \mathrm{~W} / \mathrm{m}^{2}$ resolution, TES1333 (manufactured by TES Electrical Electronic Corp., Taipei, Taiwan), and is certified to ISO9002. Temperature data are recorded at 1-minute time interval using PA Hilton data acquisition system (data logger) and its respective HDL software. A desktop computer is equipped with the measurement tools to save data acquired by the data logger and transform them into excel tables.

Repeatability tests were done and the uncertainty analysis is performed following two methods: (1) standard uncertainties for parameters measured by instruments with known precision are calculated following the rectangular distribution (since no confidence level is given and expectations for extreme values are likely) (equation 9); (2) Combined uncertainty for Thermocouples is calculated using equation 10 considering the effect of precision error of temperature measurement related to thermocouple fixation (calculated as standard uncertainty) and the repeatability standard deviation; both equations in reference to EURACHEM / CITAC Guide CG 4 [72] and are written as follows:

$$
\begin{gathered}
u(x)=a / \sqrt{3} \text { (3) } \\
u_{c}(x)=\sqrt{u(x)^{2}+S_{x}{ }^{2}}
\end{gathered}
$$


372

Where: $\mathrm{x}$ represents the parameter under measurement (temperature, solar radiation, wind speed, or humidity), $u(x)$ represents the standard uncertainty using rectangular distribution, ' $\mathrm{a}$ ' represents the certified precision of the measuring tool specified by the manufacturer, $\sqrt{3}$ which is the coverage factor, $u_{c}(x)$ represents the combined uncertainty and $S_{x}$ is the repeatability standard deviation (or repeatability uncertainty) obtained from repeatability tests that are graphed in Figure 10Figure 10 (3 examples are given). $S_{x}$ is calculated using equation 11 [49]. Repeatability test is done by cooling hot water in a container 2 times under identical test conditions for a specified time interval.

$$
S_{x}=\sqrt{\frac{1}{N(N-1)} \sum_{i=1}^{N}\left(x_{i}-\bar{x}\right)^{2}}
$$

Where: $\mathrm{N}$ is the number of repeated tests (trials), $\overline{\mathrm{x}}$ is the average reading and $\mathrm{x}_{\mathrm{i}}$ is the current actual trial reading. Table 6 Fable 6 summarizes the results of uncertainty tests done for the instruments used in the study and states the confidence level as well.

Table 6 Detailed information of measurement equipment.

\begin{tabular}{|c|c|c|c|c|c|c|c|c|}
\hline $\begin{array}{l}\text { Measured } \\
\text { Parameter }\end{array}$ & $\begin{array}{l}\text { Measuring } \\
\text { Equipment }\end{array}$ & Type & Manufacturer & Precision & Resolution & $\begin{array}{c}\text { Standard } \\
\text { uncertainty }\end{array}$ & $\begin{array}{l}\text { Combined } \\
\text { uncertainty }\end{array}$ & Confidence \\
\hline $\mathrm{T}$ & Thermocouple & K-type & - & $\pm 1.5^{\circ} \mathrm{C}$ & $0.25^{\circ} \mathrm{C}$ & 1.583 & 1.8 & $98.2 \%$ \\
\hline $\mathrm{G}_{\mathrm{s}}$ & $\begin{array}{l}\text { Solar power } \\
\text { meter }\end{array}$ & TES1333 & $\begin{array}{c}\text { TES } \\
\text { Electrical } \\
\text { Electronic } \\
\text { Corp. }\end{array}$ & $\begin{array}{c} \pm 10 \\
\mathrm{~W} / \mathrm{m}^{2}\end{array}$ & $0.1 \mathrm{~W} / \mathrm{m}^{2}$ & 5.77 & - & $94.23 \%$ \\
\hline $\mathrm{V}_{\mathrm{w}}$ & Anemometer & AR816 & $\begin{array}{c}\text { Smart } \\
\text { Sensor }^{\circledR}\end{array}$ & $\pm 5 \%$ & $0.1 \mathrm{~m} / \mathrm{s}$ & 2.88 & - & $97.12 \%$ \\
\hline$\Phi$ & $\begin{array}{l}\text { Humidity } \\
\text { sensor }\end{array}$ & - & - & $\pm 5 \%$ & $0.1 \%$ & 2.88 & - & $97.12 \%$ \\
\hline $\begin{array}{l}\text { Data } \\
\text { logger }\end{array}$ & $\begin{array}{l}\text { Data } \\
\text { acquisition } \\
\text { system }\end{array}$ & HDL & $\begin{array}{l}\text { PA Hilton } \\
\text { Ltd. }\end{array}$ & - & - & - & - & - \\
\hline
\end{tabular}
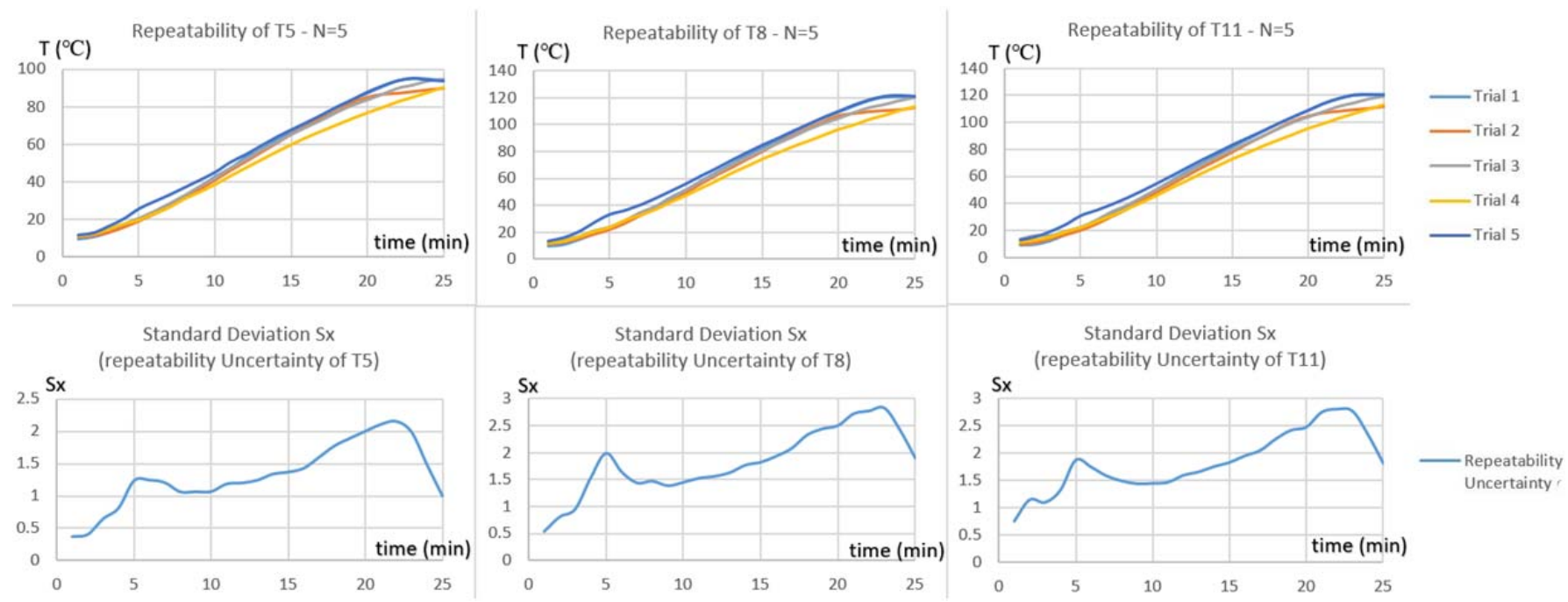

Figure 10 Repeatability tests for 3 typical thermocouples T5, T8 and T11.

The repeatability test yielded the following graphs (Figure 10Figure 10 and Figure 11Figure 11) that shows reliable results obtained by the thermocouples with the standard deviation Sx being below 2 for the range of operation related to the experiments. Higher standard deviations are accumulated at high temperatures which are far from comfort level zone. The number of trials for the repeatability tests is 5 . 


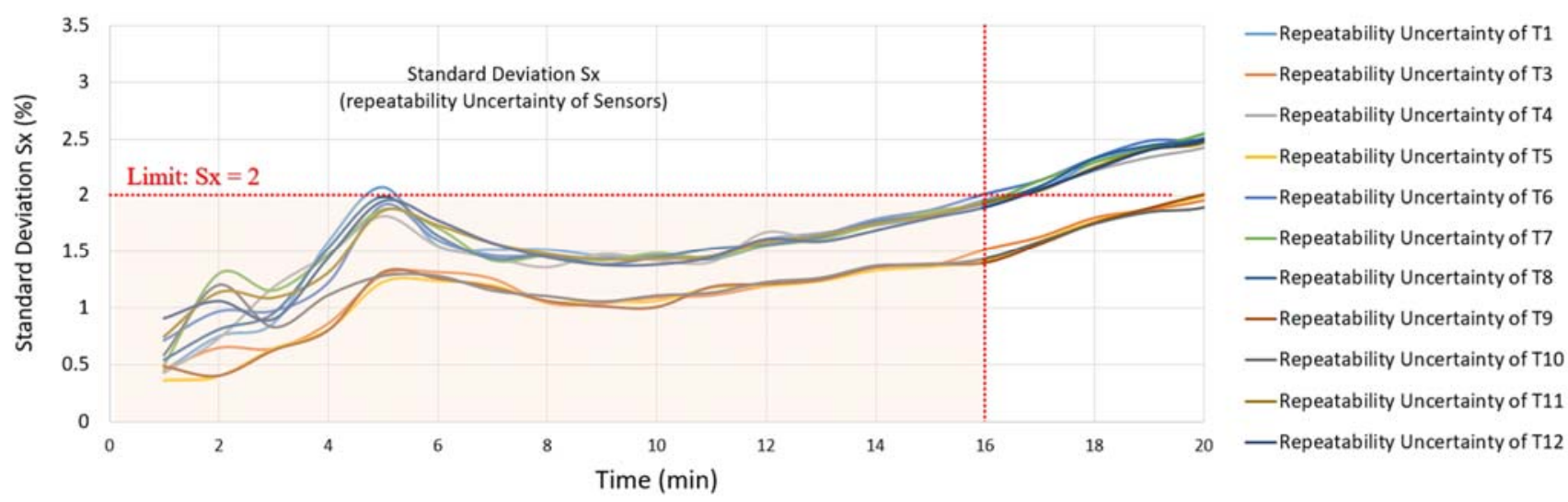

Figure 11 Standard deviation repeatability uncertainty as function of time for selective thermocouples during calibration.

\subsubsection{Control System}

The control system used, for each prototype, comprises an ST1000 (220V AC) all-purpose digital temperature controller thermostat module with an NTC thermistor temperature sensor probe. The accuracy given by the manufacturer is $+/-1{ }^{\circ} \mathrm{C}$ and the resolution is $0.1{ }^{\circ} \mathrm{C}$ with a sensor error delay of 1 minute. This gives a standard uncertainty of $0.577 \%$ (refer to equation 3). A relay module for protecting the circuit from high currents is connected prior to the pump as shown in Figure 12Figure 12.

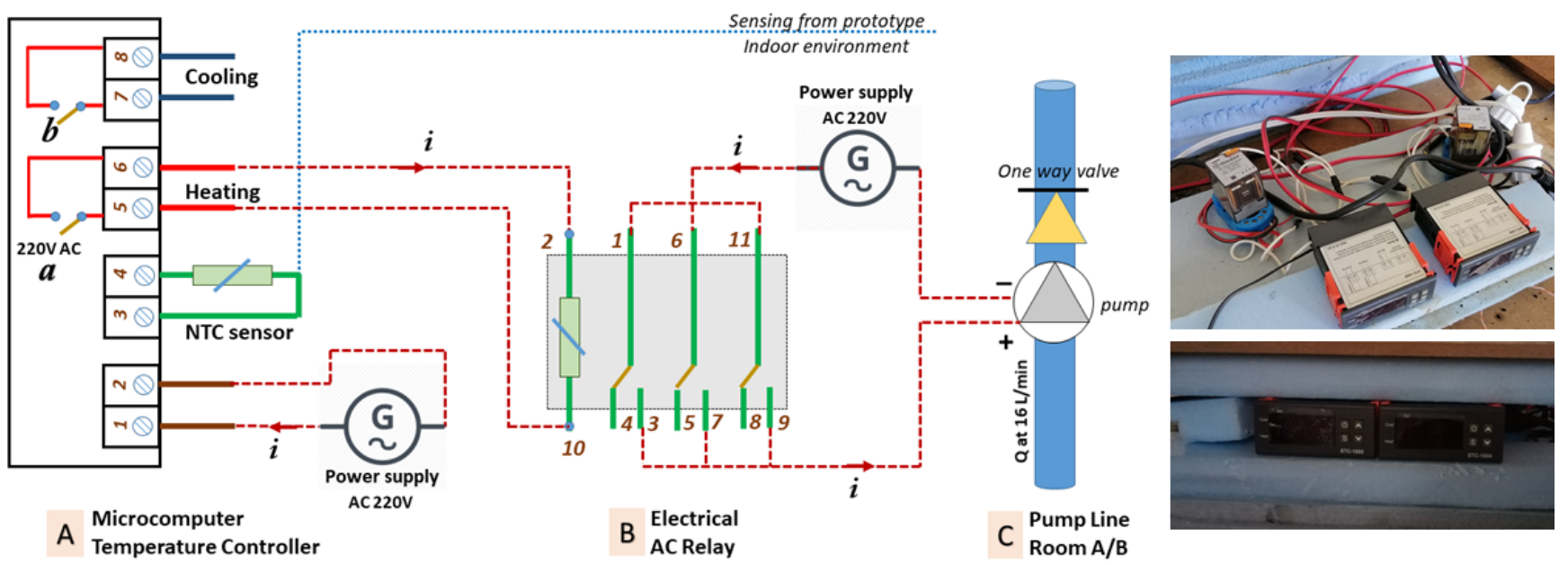

Figure 12 Control system configuration showing all connections, and a real photo of the instruments.

The procedure of testing accompanied by the control system states that: The NTC sensor is placed inside the room at a height of $0.5 \mathrm{~m}$; When the temperature of the room falls below $18^{\circ} \mathrm{C}$, switch ' $\mathrm{a}$ ' in the microcontroller closes and the AC current is allowed to pass into the AC electrical relay; The three switches in the relay will then close allowing the passage of the current into the pump that will suck hot water from the $50 \mathrm{~L}$ electrical heater that is already functioning; the floor will possess radiant heat until the temperature of the room reaches the set point which is in this case $25^{\circ} \mathrm{C}$ at which switch ' $\mathrm{a}$ ' in the microcontroller will be opened and the pump will be switched off. The procedure of control is illustrated in Figure 13Figure 13, where $\mathrm{T}_{\text {set }}$ and $\Delta \mathrm{T}$ are the set point temperature and the the temperature difference set by the user while $T_{\text {in }}$ is the indoor temperature of the room under test and is read by the NTC temperature sensor. 


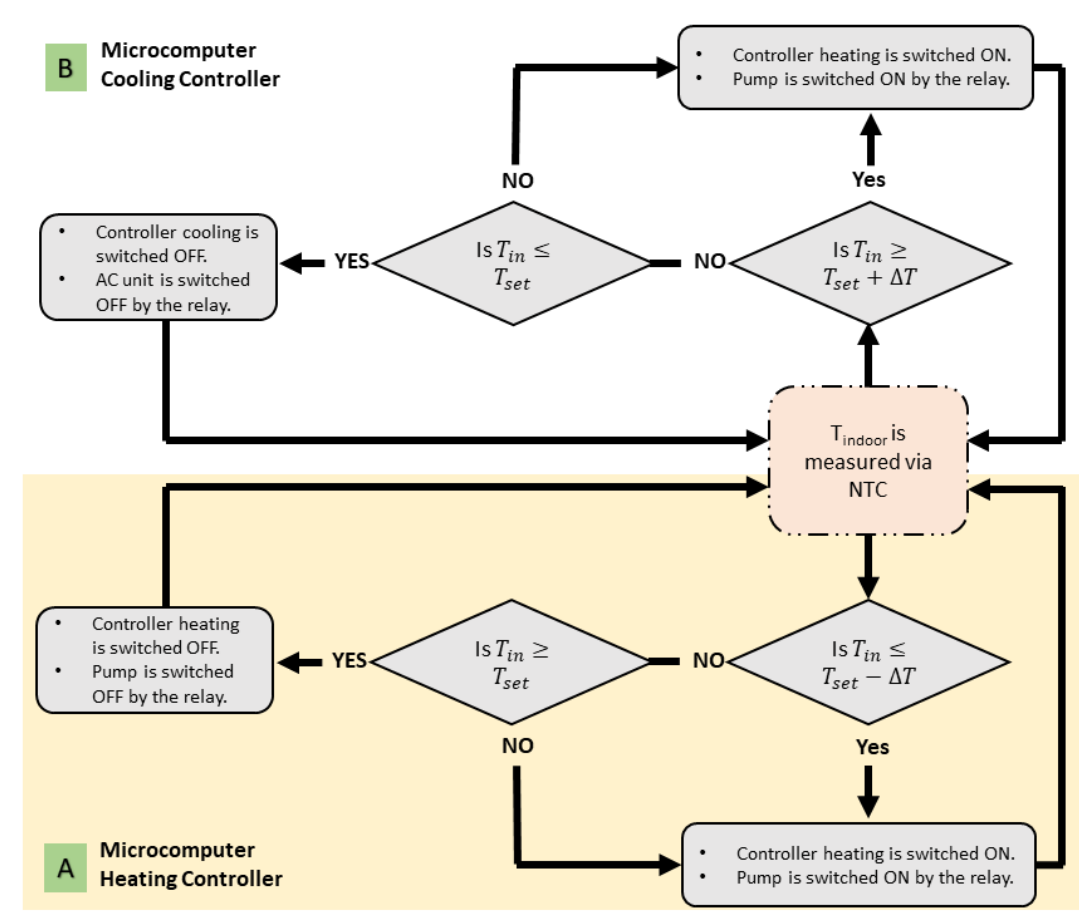

Figure 13 Flowchart for control methodology for heating and cooling systems.

\section{Results and Analysis}

The experiments were done during the terminating months of the cold winter season of 2020, namely between March $1^{\text {st }}, 2020$ and May $3^{\text {rd }}, 2020$; and the second phase of the tests took place during the middle of December 2020. Four main configurations were implemented and analyzed covering the effect of weather conditions, combining active and passive systems, effect of PCM type on thermal performance of HFRHS and effect of PCM position in regards of the floor heating system. Table 7Fable 7 below summarizes the different experimental tests and their respective details of different configurations. The locations of thermocouples for tests 1 and 5 are illustrated in Figure 14Figure 14.

Table 7 Prototypes configurations for different experimental tests.

\begin{tabular}{|c|c|c|c|c|c|c|c|}
\hline \multirow{2}{*}{$\#$} & \multicolumn{2}{|c|}{ Date \& Time } & \multirow{2}{*}{ Experimental Objective } & \multicolumn{2}{|c|}{ ThermoGreen ${ }^{\circledast}$ Specifications } & \multirow{2}{*}{$\begin{array}{l}\text { Heating } \\
\text { system }\end{array}$} & \multirow{2}{*}{ Notes } \\
\hline & Date & Time & & Prototype -A- & Prototype -B- & & \\
\hline 1 & $\begin{array}{l}\text { Monday } \\
10 / 2 / 2020 \\
\text { till } \\
\text { Thursday } \\
13 / 2 / 2020\end{array}$ & $\begin{array}{c}80 \mathrm{hr} \\
\text { start 6:00 }\end{array}$ & $\begin{array}{l}\text { Effect of PCM integration } \\
\text { with active underfloor } \\
\text { radiant heating system at } \\
\text { different weather* } \\
\text { conditions and different } \\
\text { PCM substitution layer }\end{array}$ & $\begin{array}{l}\text { Underfloor active } \\
\text { radiant with CO-PCM } \\
\text { above Heating Pipes }\end{array}$ & Reference & Hydronic & $\begin{array}{l}\text { No PCM in } \\
\text { ref. }\end{array}$ \\
\hline 2 & $\begin{array}{l}\text { Wednesday } \\
26 / 2 / 2020\end{array}$ & $\begin{array}{c}24 \mathrm{~h} \\
\text { start 6:00 }\end{array}$ & $\begin{array}{l}\text { Effect of active underfloor } \\
\text { radiant heating - combined } \\
\text { with passive PCM wall and } \\
\text { roof }\end{array}$ & $\begin{array}{l}\text { CO-PCM in all floor, } \\
\text { roof and west wall }\end{array}$ & Reference & Hydronic & $\begin{array}{l}\text { No PCM in } \\
\text { ref. }\end{array}$ \\
\hline 3 & $\begin{array}{l}\text { Wed. } \\
19 / 2 / 2020\end{array}$ & $\begin{array}{c}24 \mathrm{~h} \\
\text { start 6:00 }\end{array}$ & $\begin{array}{c}\text { Effect of PCM type in active } \\
\text { underfloor radiant } \\
\text { application }\end{array}$ & $\begin{array}{l}\text { Underfloor active } \\
\text { radiant with CO-PCM } \\
\text { in floor }\end{array}$ & $\begin{array}{l}\text { Underfloor active radiant } \\
\text { with PW-PCM in floor }\end{array}$ & Hydronic & \\
\hline 4 & $\begin{array}{l}\text { Saturday } \\
19 / 12 / 2020\end{array}$ & $\begin{array}{l}10 \mathrm{~h} \\
\text { start } \\
20: 00\end{array}$ & $\begin{array}{l}\text { Effect of PCM position in the } \\
\text { floor (below PCM plates) }\end{array}$ & $\begin{array}{l}\text { Underfloor active } \\
\text { radiant with CO-PCM } \\
\text { below Heating Pipes }\end{array}$ & Reference & Hydronic & $\begin{array}{l}\text { No PCM in } \\
\text { ref. }\end{array}$ \\
\hline
\end{tabular}



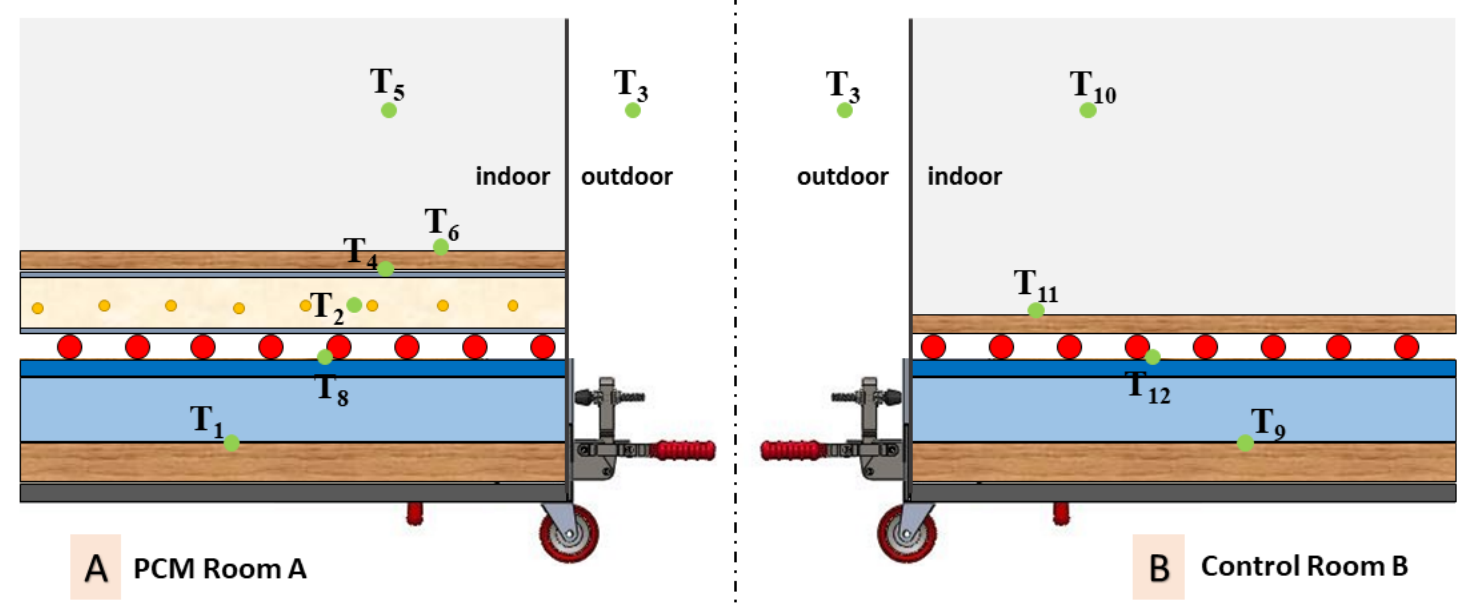

Figure 14 Location of K-type thermocouples for temperature measurement in tests 1, 2, and 3.

\subsection{Active radiant heating with PCM under different weather conditions}

The preliminary tests investigated the effect of CO-PCM placed in the floor, above the hydronic radiant pipes and compared with a control room with no PCM. Figure 15Figure 15 shows the temperature variations recorded by the floor and room sensors for prototypes A (containing CO-PCM plates) and B (deprived from PCM and considered as control) during three consecutive days encountering variable weather conditions (refer to Figure 16Figure 16). It is shown that for the first cold rainy day with $78 \%$ relative humidity and a wind speed varying between 0.4 and $1.2 \mathrm{~m} / \mathrm{s}$, the first heating phase lasted $18.567 \mathrm{hr}$. for the Active CO-PCM room. Then, the cooling phase remains for $5.33 \mathrm{hr}$. as the ambient temperature fluctuates between 5.7 and $11.7^{\circ} \mathrm{C}$. However, for the control room 4 heating-cooling cycles are observed with the first cycle having heating and cooling durations of $8.5 \mathrm{hr}$. and $1.033 \mathrm{hr}$., respectively. This indicates that the PCM is storing thermal energy in the form of latent heat after which the penetration of heat continues to the floor surface in a slow manner. Then, the heating unit is powered off so the PCM releases its heat slowly maintain the room temperature with its thermal comfort range for more time. The room temperatures are illustrated in Figure 17Figure 17. It is observed that the fluctuations in the control room (within the comfort zone by means of the control system, i.e. between 18 and $24{ }^{\circ} \mathrm{C}$ ) are eliminated by means of PCM in Active CO-PCM room. Where the number of heating-cooling cycles is reduced from 12 to 5 compared to the control room. The observed water heating tubes temperature fluctuations (between 50 and $65^{\circ} \mathrm{C}$ ) is due to the thermostatic effect of the boiler.

As the ambient temperature decreased in the second day of the experiment, the heating duration for the control room lasted for $11.45 \mathrm{hr}$. followed by a temperature decay lasting $1.733 \mathrm{hr}$. bearing in mind that the weather was cloudy with a relative humidity of $68 \%$ and a wind speed varying between 0.4 and $1.6 \mathrm{~m} / \mathrm{s}$. As the weather starts to get warmer (sunny day but with no solar radiation reaching the prototypes) and the humidity decreases to the upper comfort bound of $60 \%$, the heating-cooling cycles increased from 1 to 2 and from 2 to 4 in rooms A and B, respectively.

The floor surface temperature during the three days was varying between 19.7 and $28.6^{\circ} \mathrm{C}$, as the upper surface of PCM macro-containers varied between 21.3 and $39.8^{\circ} \mathrm{C}$. However, for the control room, the floor surface reached a temperature of $37.7^{\circ} \mathrm{C}$ which is beyond thermal comfort. The results revealed within the graphs depict that CO-PCM is suitable for load shifting and indoor temperature fluctuations reduction thus maintaining residents thermal comfort. 


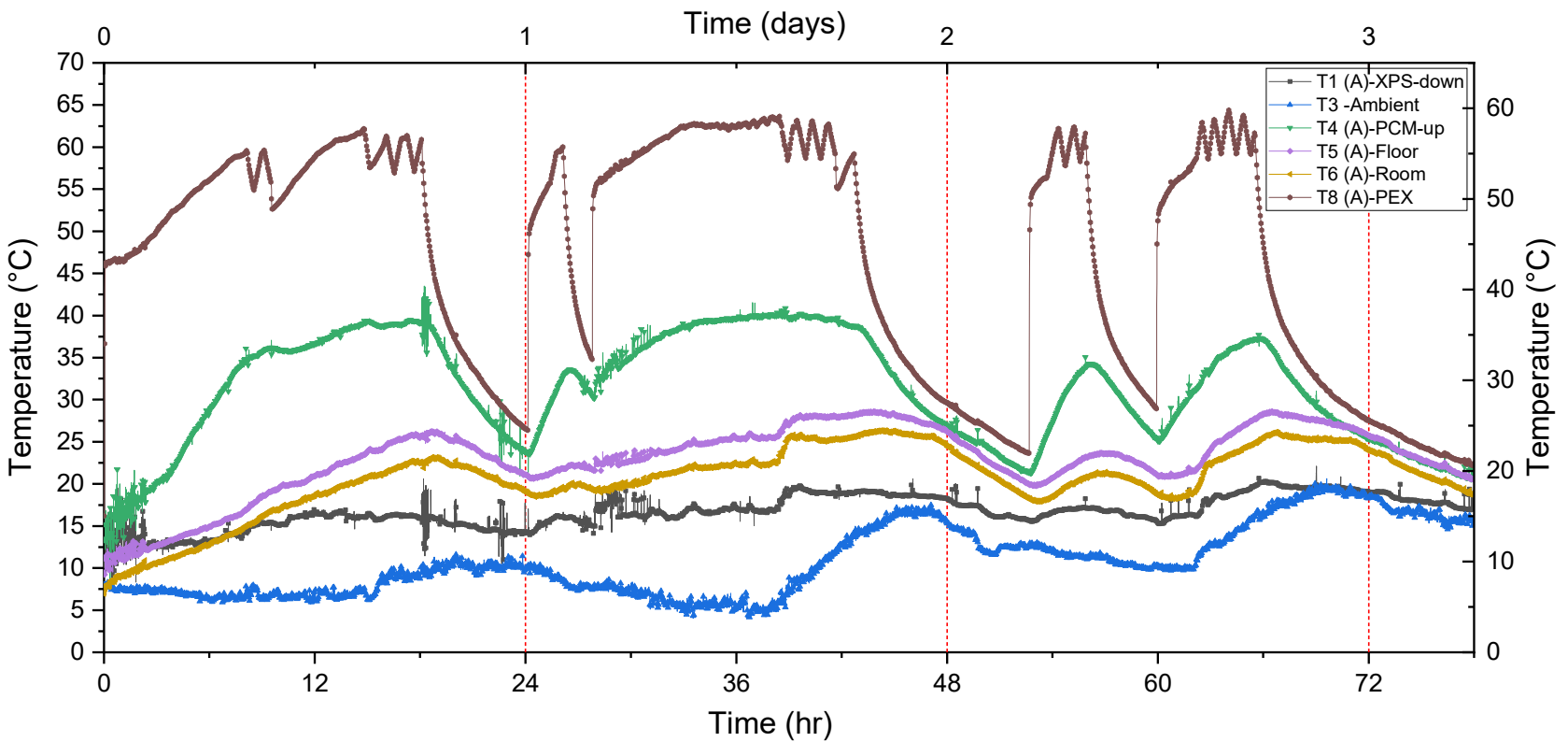

453

Time (hr)

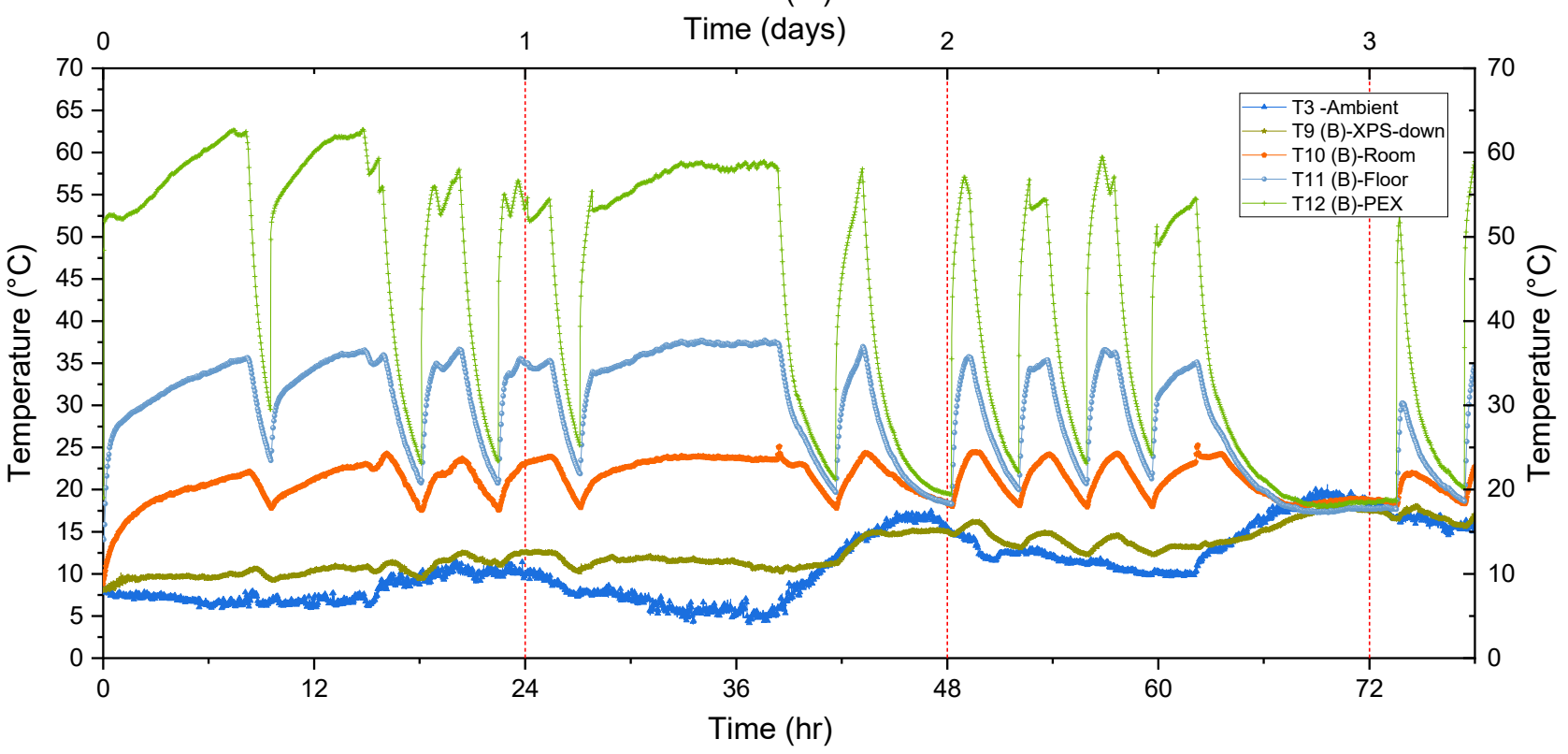

Figure 15 Temperature variations recorded by the floor and room sensors for prototypes $A$ (containing the $P C M$ ) and $B$ (deprived from PCM - control) during test 1 for different weather conditions.

The power curves showing the pump power consumption as function of time for the two test prototypes are shown in Figure 18Figure 18. It is clear from the curves that there is a reduction in energy demand fluctuation thus a decrease of start-up and shut-down processes of the electrical boiler and pump, thus maintenance requirements are reduced. 


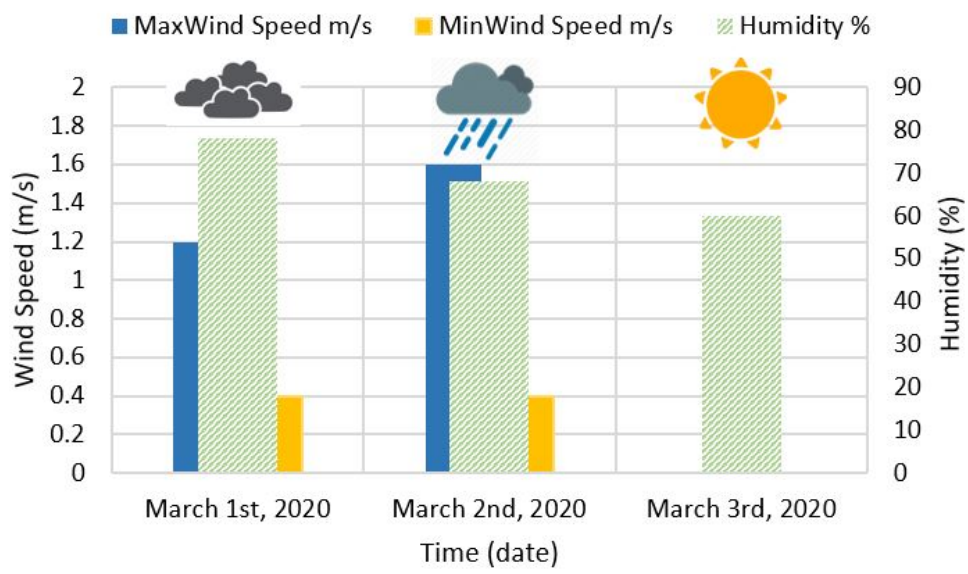

Figure 16 Maximum and minimum wind speeds, weather conditions and average humidity during experiment 1.

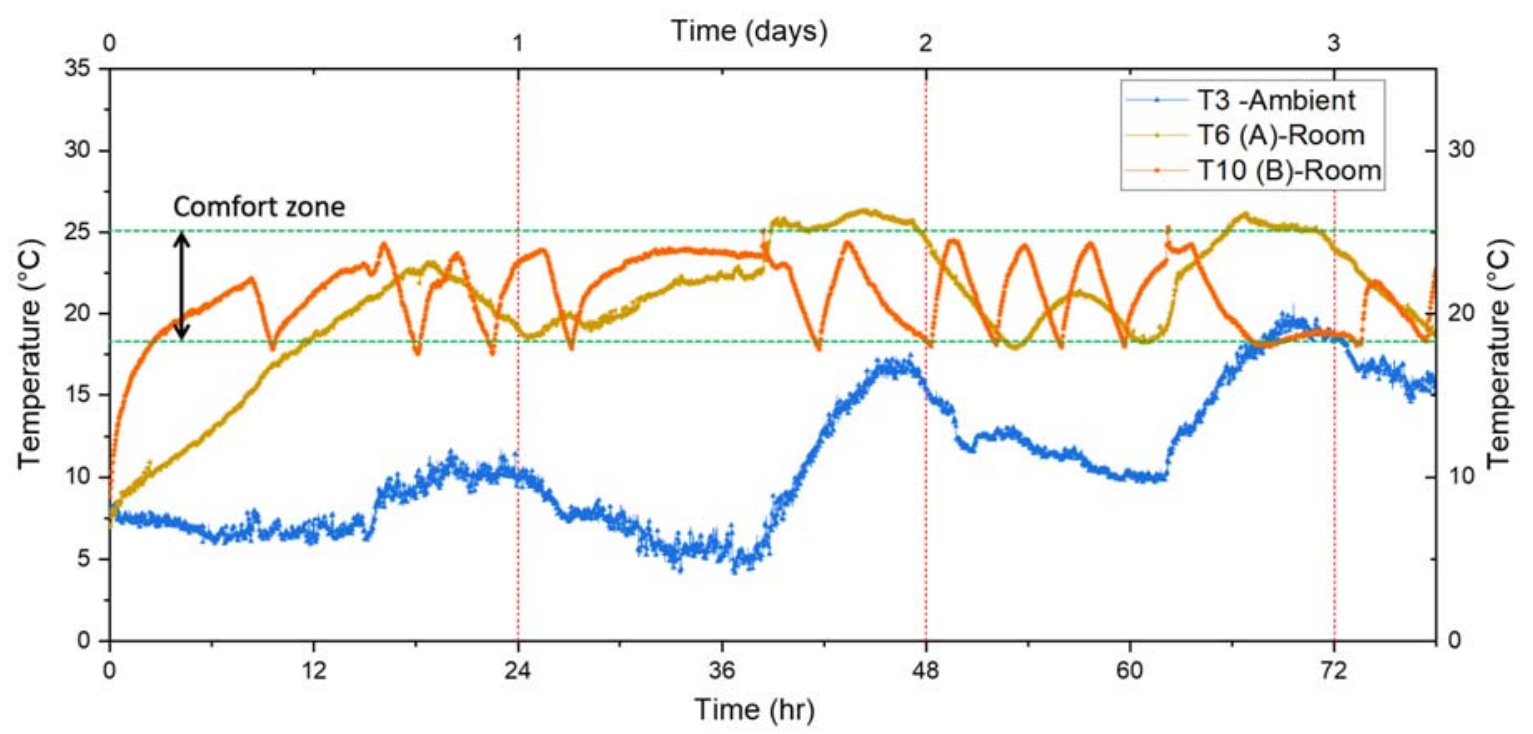

Figure 17 Variation of room temperatures for experiment 1 as function of time within three testing days. 


\section{Power Consumption - Room A}

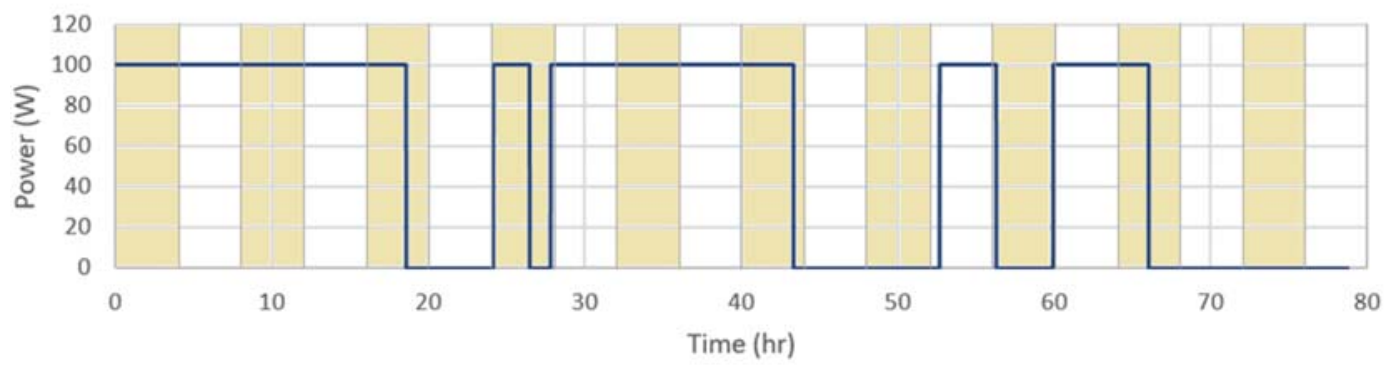

Power Consumption - Room B

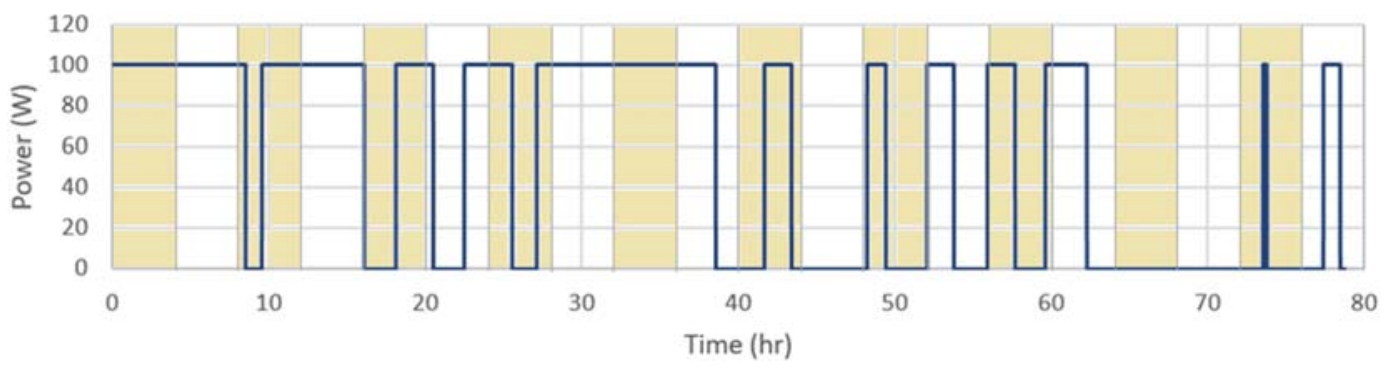

Figure 18 Pump power consumption for rooms A and B during test 1.

\subsection{Combining active and passive applications}

The second experiment was focused on combining the active CO-PCM floor system with passive PCM layers at the west wall and roof. In this case, two plates filled with CO-PCM were installed in the west wall of prototype A with the remaining vacancy ${ }^{3}$ being occupied with XPS insulation. The roof also contained two PCM plates with XPS at the remaining edges to comply with the west wall design. A clear presentation is given in Figure 2Figure $z$ for the roof.

The plots of the temperatures recorded for the different layers of the floor, indoor and outdoor are illustrated in Figure 19Figure 19. It is shown that during 18 hours of continuous data acquisition, the PCM in the tested room was capable of shifting the load by $4.184 \mathrm{hrs}$. The heating durations for the $1^{\text {st }}$ cycle were $4.983 \mathrm{hr}$. and $1.65 \mathrm{hr}$. in rooms A and B respectively. However, room, floor, PCM plate upper surface, and PEX temperatures decreased from their peak values to lower values during $4.184 \mathrm{hr}$. and $4.15 \mathrm{hr}$. in rooms A and B, respectively. The decay in temperatures during cooling had a lower slope value in comparison with the decay in the control room. Three heating-cooling cycles were observed for the control room while two heating-cooling cycles were observed for the PCM room. A plot for the power consumption is illustrated in Figure 20Figure 22 showing the intervals of high and low peak loads based on the Tariff policy of electricity within the site of experiment, Lebanon. The shaded parts of the plot represent the time of low-peak load and the unshaded parts represent high-peak load interval (discussed in details in section 5). It is obvious that the presence of PCM in floor, wall and roof caused the complete shifting from high to low peak loads. For instance, the operation of the heating system in the control room occurred for $0.667 \mathrm{hr}$. within low-peak load and for $3.933 \mathrm{hr}$. within high-peak load; However, the presence of PCM altered the thermal behavior of the room and shifted the load so that $0.983 \mathrm{hrs}$. were within high-peak load, and $4 \mathrm{hr}$. were within the low-peak load. This variation resulted in cost savings that are discussed further more (section 5).

It is depicted in the figures of temperature profiles that the heating duration when PCM is present above the PEX tubes is relatively high, and causes a delay in reaching the thermal comfort. This is favorable to a certain

\footnotetext{
${ }^{3}$ The remaining vacancy is a result of having the plates each with a width of $46.6 \mathrm{~cm}$ and the total height available within the side walls is $120 \mathrm{~cm}$, thus $26.6 \mathrm{~cm}$ remains and are occupied by XPS.
} 
limit where temperature fluctuations decrease. On the other hand, such long time increases the residents'

dissatisfaction. As for the temperature of the room that have reached $24^{\circ} \mathrm{C}$, the CO-PCM in the room did not melt and thus the performance of PCM in the roof was similar to the XPS insulation where sensible heat loss penetrated through the PCM whereas the presence of PCM in wall encountered partial melting. For that, it is recommended to choose the PCM in the roof and wall within the margins of $18-20^{\circ} \mathrm{C}$ as for benefiting from the complete latent energy of the PCM. For higher temperature set value (i.e. $30^{\circ} \mathrm{C}$ for example) wall and roof PCM could be functioning with their complete effectiveness, however, room temperature will be exceeded. Also, one important consideration is the use of auxiliary electric mats placed below the PCMs present in the wall and the roof so that upon heating the room, complete melting for CO-PCM occurs all over the envelope.

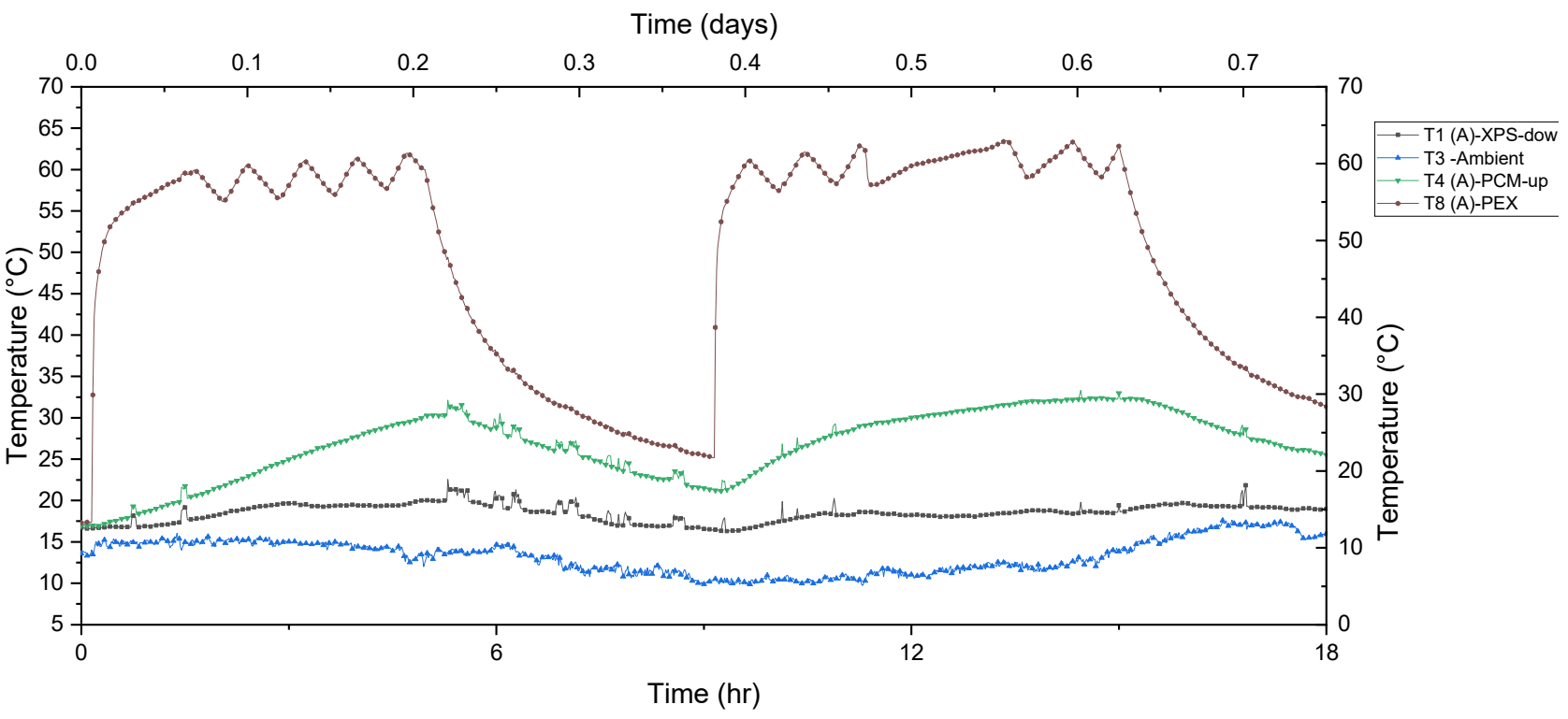

505

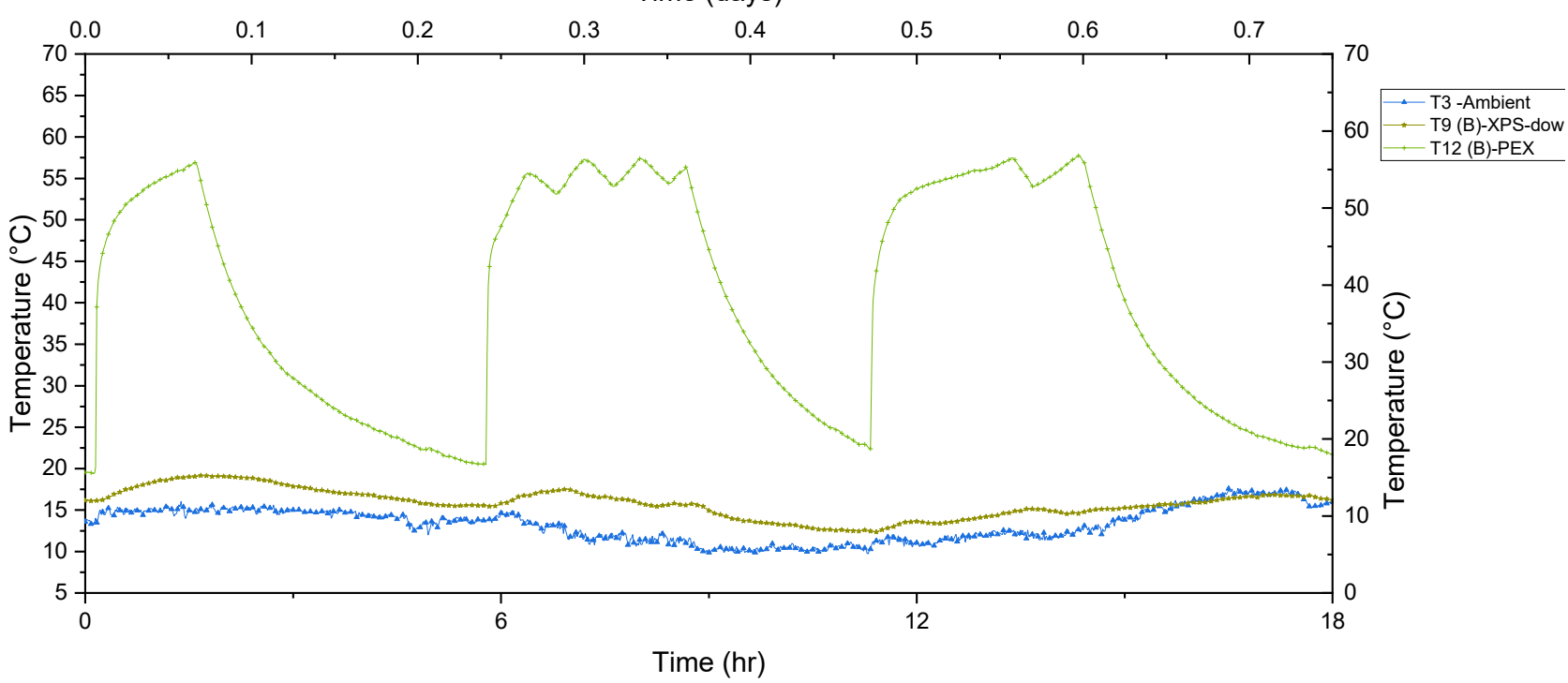

Figure 19 Temperature variations recorded by the floor and room sensors for prototypes $A$ (containing PCM in floor, west wall and roof) and $B$ (deprived from PCM - control) during test 2. 
Power Consumption - Room A

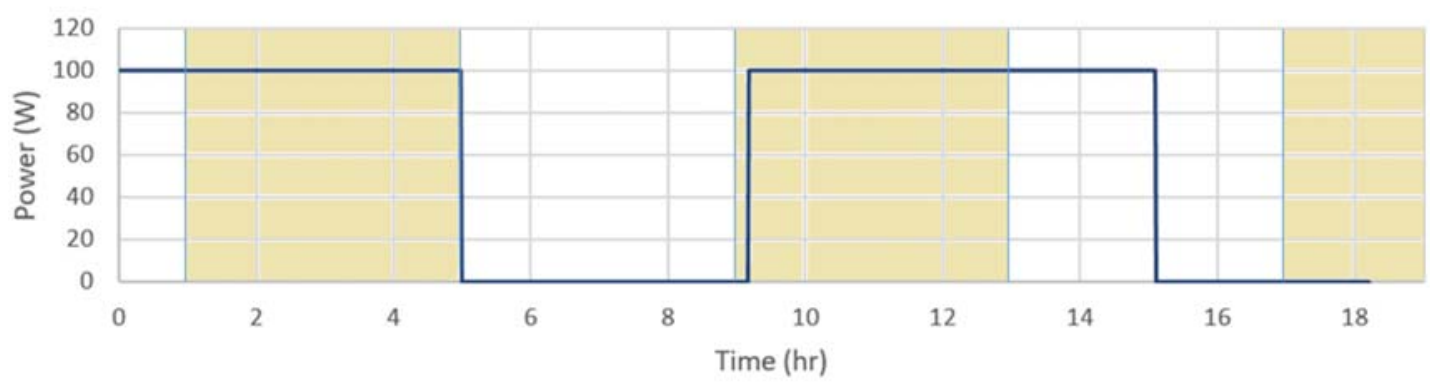

Power Consumption - Room B

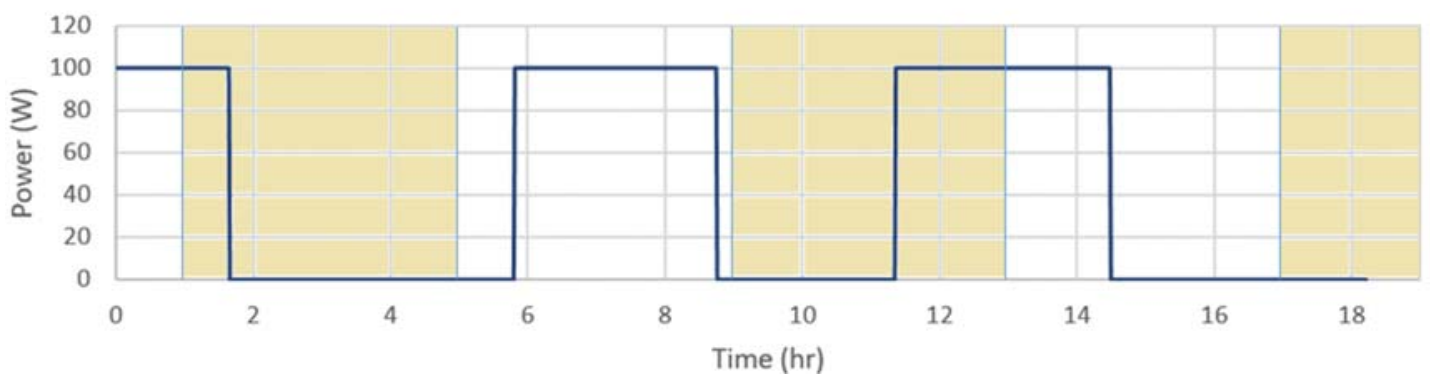

Figure 20 Pump power consumption for rooms A and B during test 2.

\subsection{Comparison between CO-PCM and PW-PCM}

The third experimental test is directed toward comparative investigation of the thermal performance of the two prototypes having different PCM types (different thermo-physical properties especially: melting temperatures and latent heat). The preliminary results are shown in Figure 21Figure 21, where it combines readings from the two prototypes. Room A contained CO-PCM above the heating tubes and is considered as the control; and room B contained paraffin wax (PW-PCM), also above the heating tubes, and is considered the variable test (refer to Figure 14Figure 14-A to check the layers' order). Table 8 shows the thermo-physical properties of CO and PW PCMs.

The start of the heating cycles had the same trend in both rooms, from time 0 till $9.683 \mathrm{hr}$. at which PW-room B reached $24{ }^{\circ} \mathrm{C}$ where the pump is powered off and a gradual decay in temperature starts accounted by release of stored energy in PW plates. However, the heating in room B continued for an extra $6.95 \mathrm{hr}$. to reach the desired room temperature, before its gradual decrease accompanied by the heat release from melted CO. After that, PWroom starts a new heating cycle where as CO-room remains decaying within thermal comfort. It is observed that at the time heating stops in cycle 1 of room $\mathrm{B}$, the room temperature remains increasing to $27.6^{\circ} \mathrm{C}$ which is caused by the relatively high temperature of the PCM plates (where the melting point of $\mathrm{PW}$ is $58^{\circ} \mathrm{C}$, thus replacing the role of the PEX tubes at this stage).

A plot of the power consumption shown in Figure 22Figure 22 indicates that although there is load-shifting accompanied by CO-PCM, the large margin of heating time (caused probably of the relatively low thermal conductivity of CO-PCM compared to PW-PCM, or due to experimental sources of error: incomplete thermal contact between layers of PCM and PEX for example) over continuous tariff shifts of $4 \mathrm{hr}$. each, is not favorable. PW in this case shows better thermal response, with less time of operation within high-peak and low-peak load margins.

Summing up the aforementioned and analyzed tests, Figure 23Figure 23 compares the number of heating-cooling cycles for control and test prototypes for each test. It is shown that lower number of cycles is always a property 
Figure 21 Temperature variations recorded by the floor and room sensors for prototypes $A$ (containing CO-PCM in floor) and $B$ (containing PW-PCM in floor) during test 3.

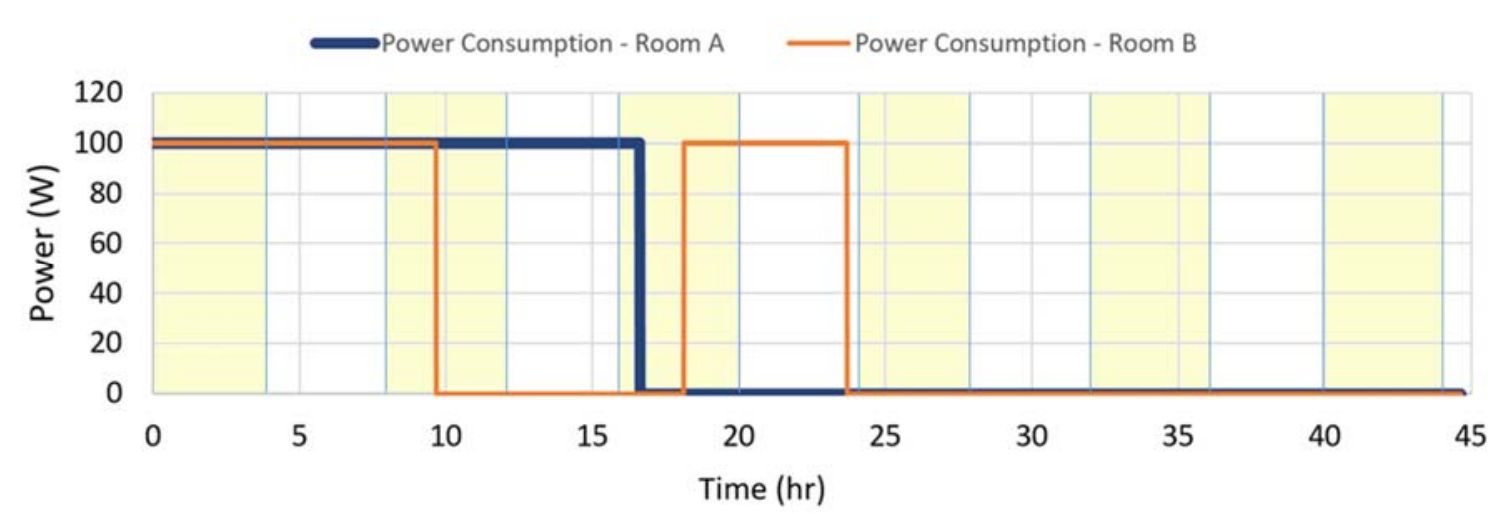

Figure 22 Pump power consumption for rooms $A$ and B during test 3.

of the tested rooms containing the PCM. This ensures the two major advantages of using PCM in active floor system, and passive walls and roof: (1) Enhancement of thermal comfort by decreasing indoor temperature fluctuations, and (2) Load shifting resulting in cost savings for regions of variable electricity tariff policy shifts.

Table 8 Thermo-physical properties measured in TQP laboratories.

\begin{tabular}{|c|c|c|c|c|}
\hline PCM & $\operatorname{Tm}\left({ }^{\circ} \mathrm{C}\right)$ & $\mathrm{Cp}(\mathrm{kJ} / \mathrm{kg} . \mathrm{K})$ & $\mathrm{L}_{\mathrm{H}}(\mathrm{kJ} / \mathrm{kg})$ & $\mathrm{K}(\mathrm{W} / \mathrm{m} . \mathrm{K})$ \\
\hline $\begin{array}{l}\text { Coconut oil } \\
\text { (CO) }\end{array}$ & 25 & 2.174 & 102.97 & $\begin{array}{c}0.321 \text { [63], } 0.5 \\
\text { [66] }\end{array}$ \\
\hline $\begin{array}{l}\text { Paraffin wax } \\
\text { (PW) }\end{array}$ & $58-60[60]$ & - & 189 [60] & $0.21[60]$ \\
\hline
\end{tabular}

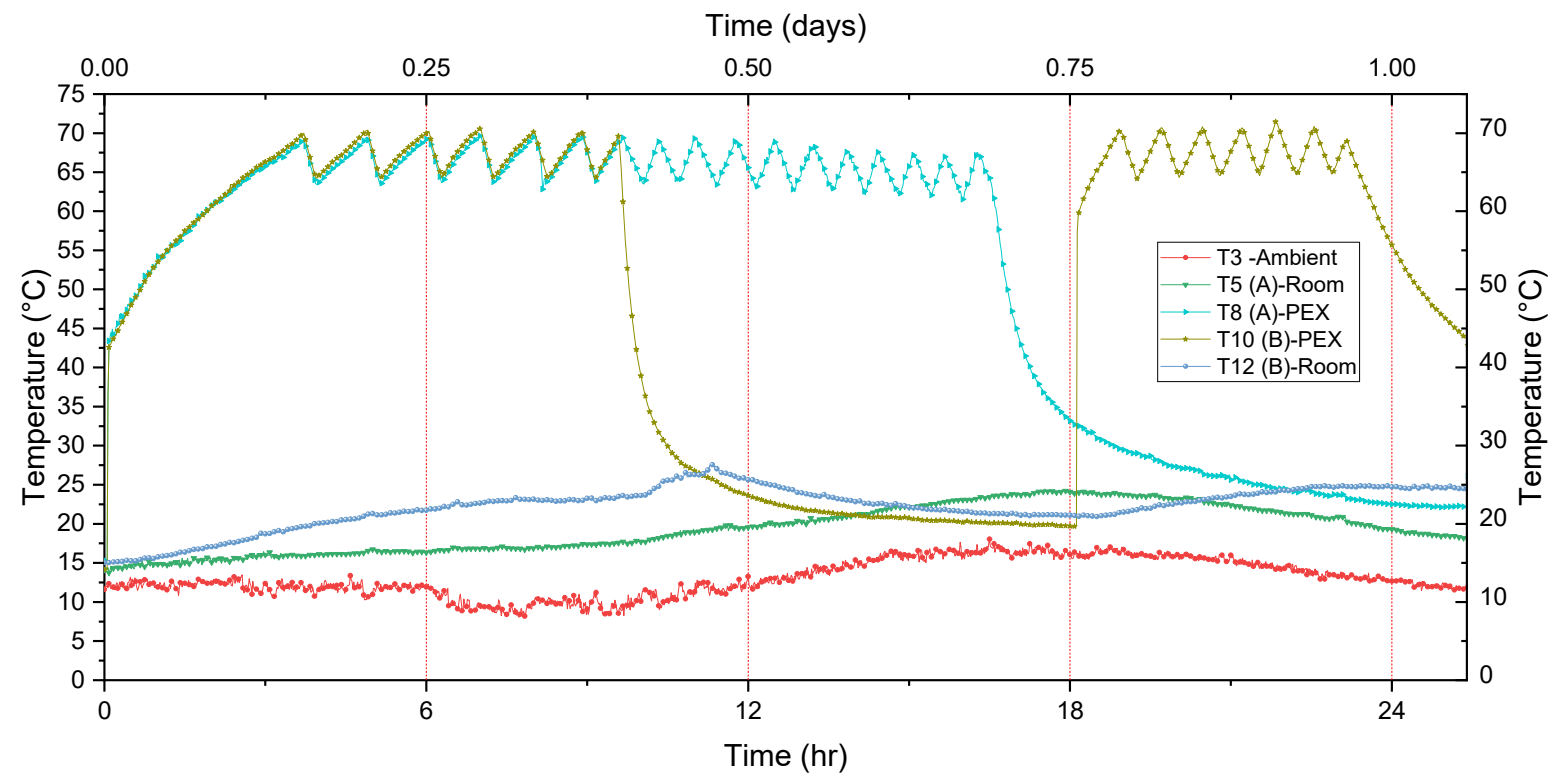




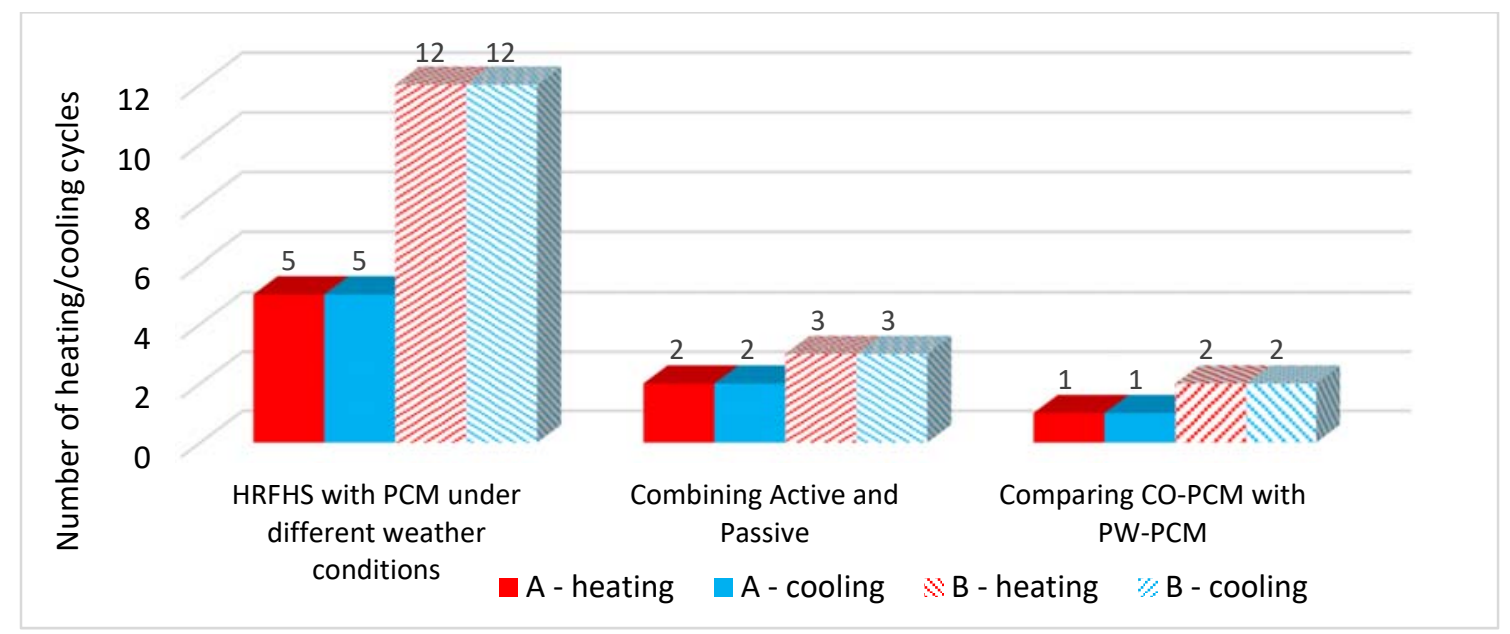

Figure 23 Comparison for the number of heating and cooling cycles in rooms A and B at various tests.

\subsection{Effect of PCM position within the floor (CO-PCM Below HRFHS)}

The last test in this study investigates the effect of CO-PCM position in reference to test 1. CO-PCM plates were placed below the PEX tubes as shown in Figure 24Figure 24. The EPS layer that holds the hydronic tubes is eliminated and the tubes are connected to the wood layer by means of $18 \mathrm{~mm}$ diameter clips, to maintain the spiral layout. During this test, the prototypes were rotated such that the doors are at the west direction. The test was performed among two stages: (1) $10 \mathrm{hrs}$. of variable weather conditions taking into account solar radiation effect, and (2) 24 hrs. of stable weather with no solar radiation effect (shadings are used and the focus was on ambient temperature).

Stage 1 - The results are plotted on the same graph illustrated in Figure 25Figure 25. It is shown that the temperature of the hydronic pipes increased and remained above $55{ }^{\circ} \mathrm{C}$ upon heating when the pumps were switched on, leading to an increase in PCM and floor surface temperatures. During the first $2 \mathrm{hrs}$. of the test, the control test room (B) was subjected to solar radiation ranging between 628 and $819 \mathrm{~W} / \mathrm{m}^{2}$, wind speed of $0.2-$ $0.8 \mathrm{~m} / \mathrm{s}$ and humidity ranging between 60.9 and $62.6 \%$. The solar radiation was facing the south wall of room B and penetrating through the window. This caused the slightly higher slope of room temperature compared to room A, where the room temperature was increased from 18 to $27^{\circ} \mathrm{C}$ by means of the PEX and solar radiation - this is reflected by the increase of floor surface temperature reaching $39^{\circ} \mathrm{C}$ at the end of the cycle which is less than the floor surface temperature reached in room A before reaching the room desired temperature. As time continues increasing to reach $2.83 \mathrm{hr}$., the floor surface temperature in room A continues its gradual increase to reach 42 ${ }^{\circ} \mathrm{C}$, while the room temperature reaches $26.5^{\circ} \mathrm{C}$. It is shown that the PCM till this point did not melt, and its temperature is increasing sensibly from 12.4 to $25^{\circ} \mathrm{C}$ at which it starts melting.

The delay of $1 \mathrm{hr}$. to reach the comfort set point in room A compared to B was mainly due to the advantage of having solar radiation in room B. Then, all temperatures decrease during $2 \mathrm{hrs}$. at which both rooms are heated again, with solar radiation being eliminated from room B. It is observed that the temperature of PCM remained increasing till $28^{\circ} \mathrm{C}$ and remained at this temperature although the PEX tubes are heated again; this indicates the phase change phenomena (melting) of the PCM. The floor surface temperature and thus the room temperature in room A reaches the set points before room $\mathrm{B}$, and the decay in temperatures had a lower slope in room $\mathrm{B}$ after the pump is switched off indicating the functioning of PCM in releasing its stored heat. Two similar cycles occurred where the durations of heating and cooling in room A were 0.65 and $2.53 \mathrm{hrs}$.; and in room B were 0.88 and 2.27 hrs., ensuring a difference of $0.26 \mathrm{hr}$. in cycle $2(0.37 \mathrm{hr}$. in cycle 3$)$. 

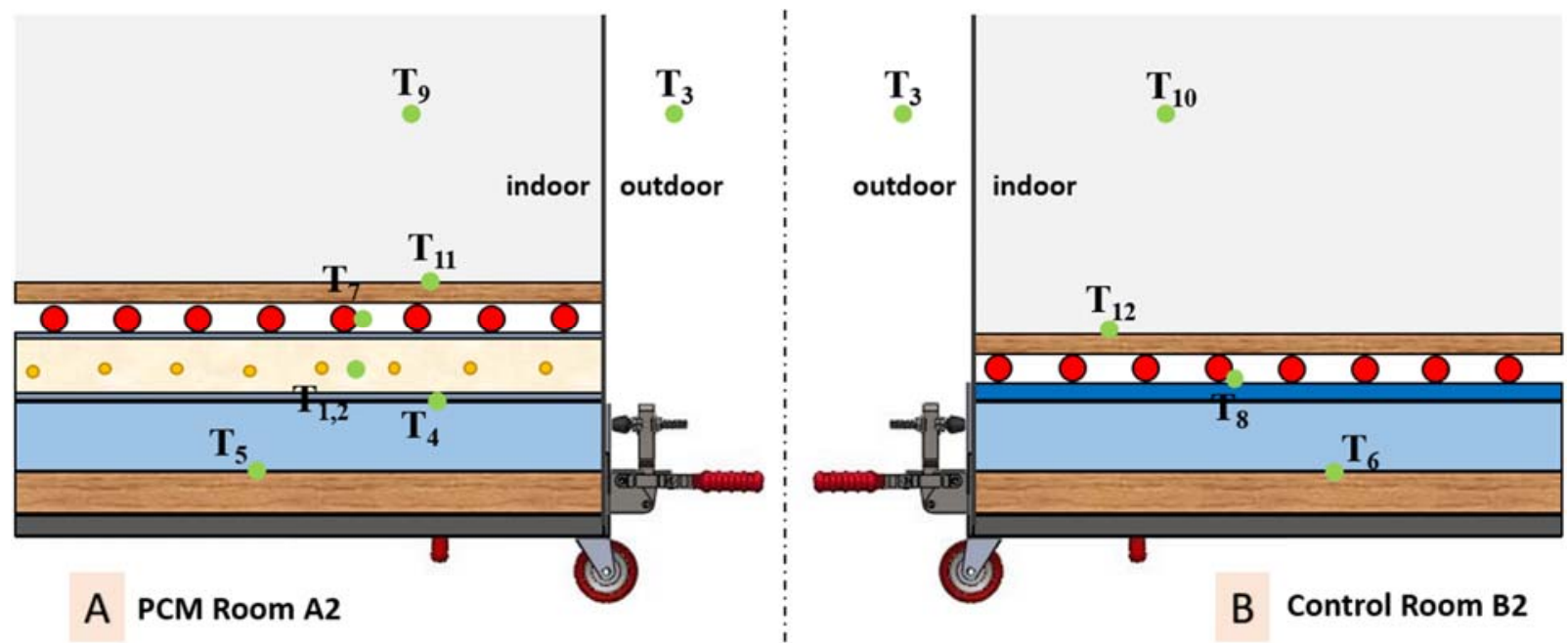

Figure 24 Location of K-type thermocouples for temperature measurement for test 4.

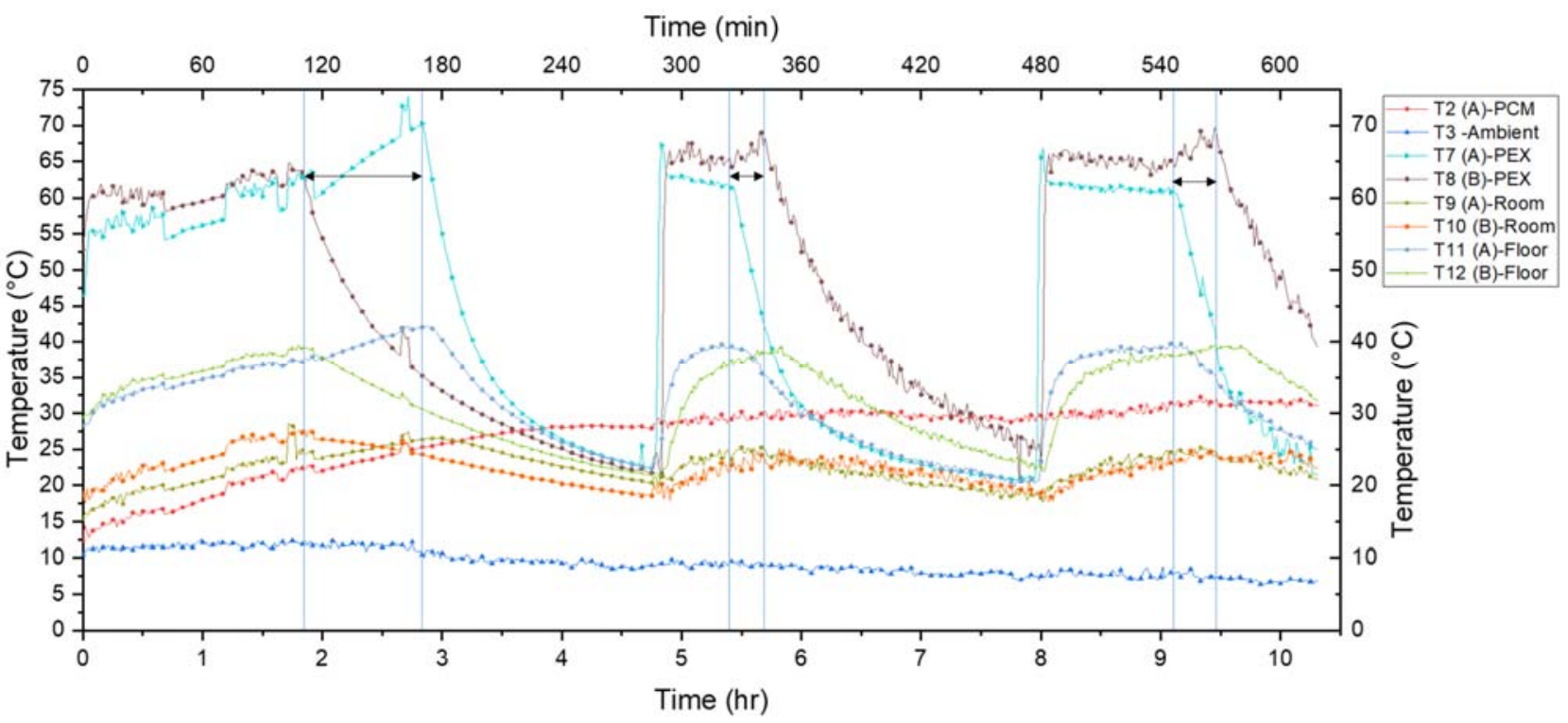

Figure 25 Temperature variations recorded by the floor and room sensors for prototypes A (containing CO-PCM in floor below PEX tubes) and B (control) during test 4 - stage 1.

Stage 2 - The test in stage 2 was conducted for a complete day with shadings used to eliminate the effect of solar radiation. Two graphs showing the results of the temperature distribution of the floor and room for prototypes A and B are illustrated in Figure 26Figure 26. Three heating-cooling cycles are observed in both rooms. To have a closer view of the detailed outcomes, floor surface and room temperatures with ambient outdoor temperature are plotted against time in Figure 27Figure 27. As depicted in the graph, for a relatively cold weather of an outdoor ambient temperature fluctuating between 7.6 and $13.6{ }^{\circ} \mathrm{C}$, a total heating duration of $4.784 \mathrm{hrs}$. in the control room B is reduced to $3.418 \mathrm{hrs}$. in room A by means of CO-PCM. This indicates the capability of the PCM in saving energy. The concept behind this observation is that the hydronic PEX tubes are radiating and conducting heat on all directions of their circumferences. Heat that is directed toward indoor is the useful heat, whereas heat that is being transmitted downward in the floor is being lost. The presence of PCM below the PEX tubes, captures this heat and releases it when the pump is switched off, thus forming a source of heat energy again to the room.

Room temperatures increase from 18 to $24^{\circ} \mathrm{C}$ in a higher slope within room A compared to room $\mathrm{B}$ however the phenomenon is opposed while discharging (the slope of room temperature decay is smaller for rom A). This 
leads to smaller heating times and larger cooling times in the presence of PCM. Also, it is observed that after the last heating cycle, the decay in temperatures of room and floor surface for A and B encountered some differences. The slopes of temperature decay for A were smaller than that for B indicating the PCM functioning; And at the end of the test a difference of $2.5^{\circ} \mathrm{C}$ in room and $1{ }^{\circ} \mathrm{C}$ in floor surface temperatures between $\mathrm{A}$ and $\mathrm{B}$, respectively, were obtained.

Finally, a plot of the power input for rooms A and B consumed by pumps delivering hot water for heating is illustrated in Figure 28Figure 28. It is shown clearly that the duration of heating in room B is larger than that in room $\mathrm{A}$, and that, as aforementioned before, there is a delay in powering on the pump in room $\mathrm{A}$ as an effect of PCM. The energy stored by the PCM is reused for maintaining thermal comfort within the room. Therefore, placing PCM below the heating system results in energy savings that are translated into cost saving furthermore, 616 even with a defined electricity cost with stable rate (no differentiation for electricity cost into high-peak and lowpeak shifts).

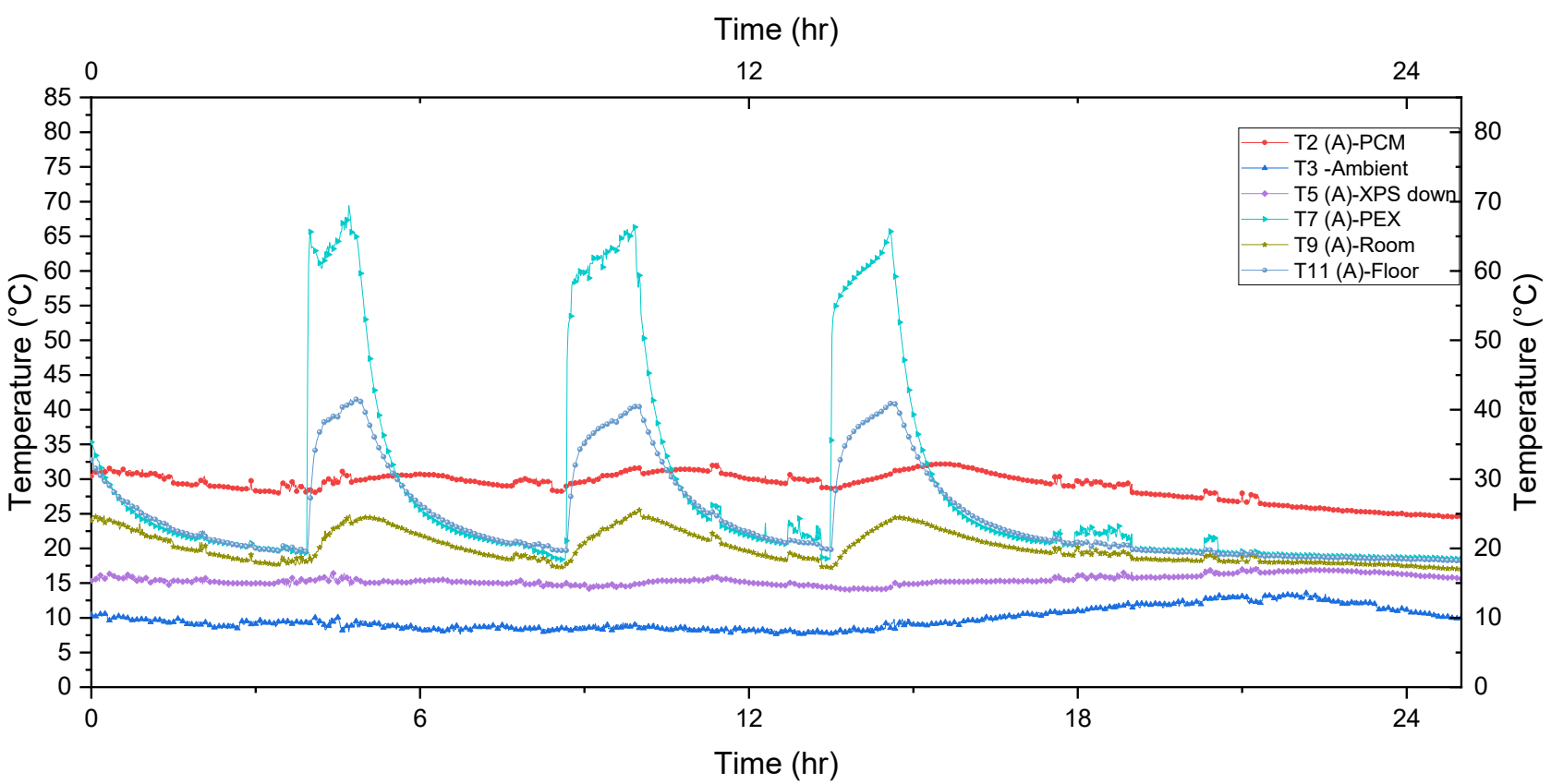


Time (hr)

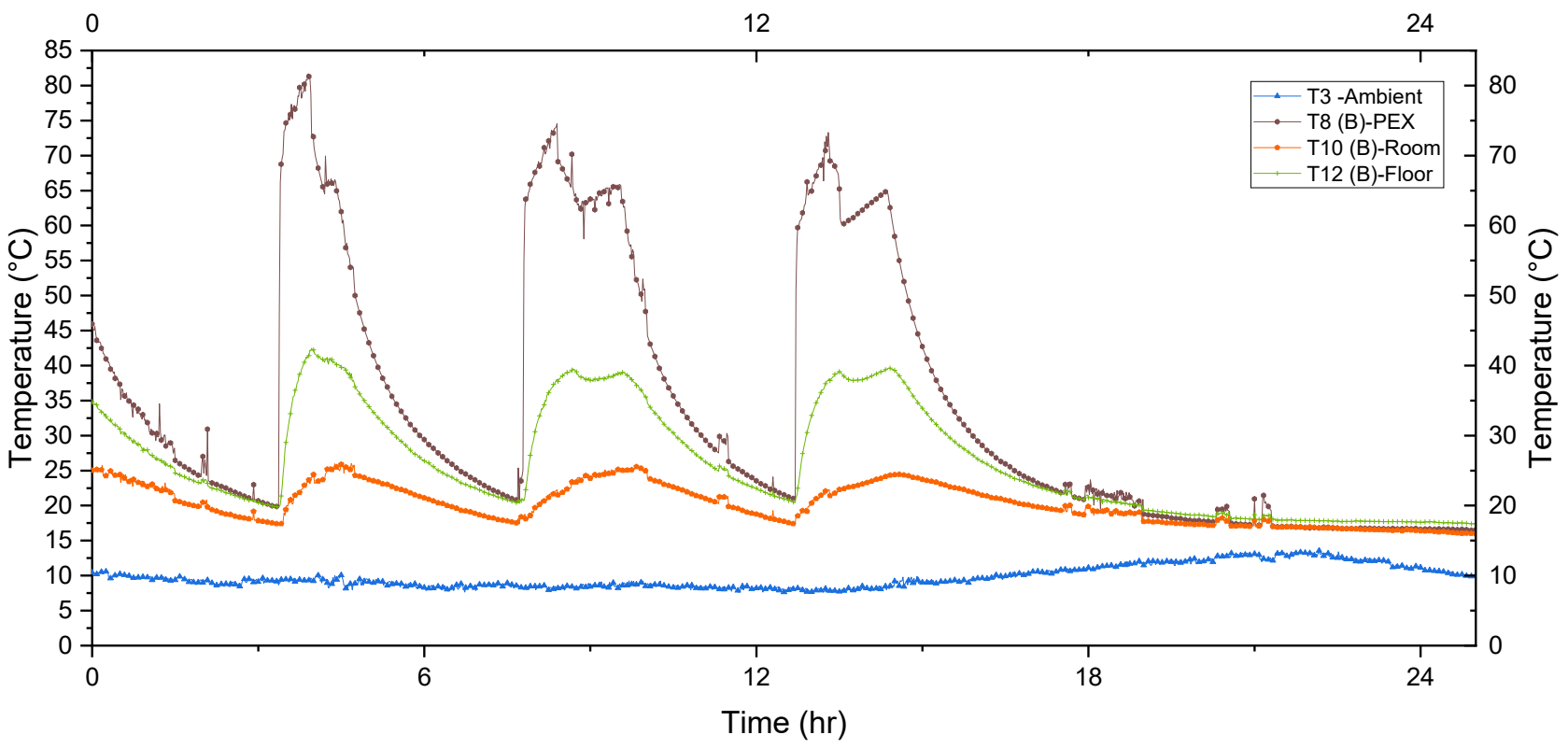

619 Figure 26 Temperature variations recorded by the floor and room sensors for prototypes A (containing CO-PCM in floor 620 below PEX tubes) and B (control) during test 4 - stage 2.

Time (hr)

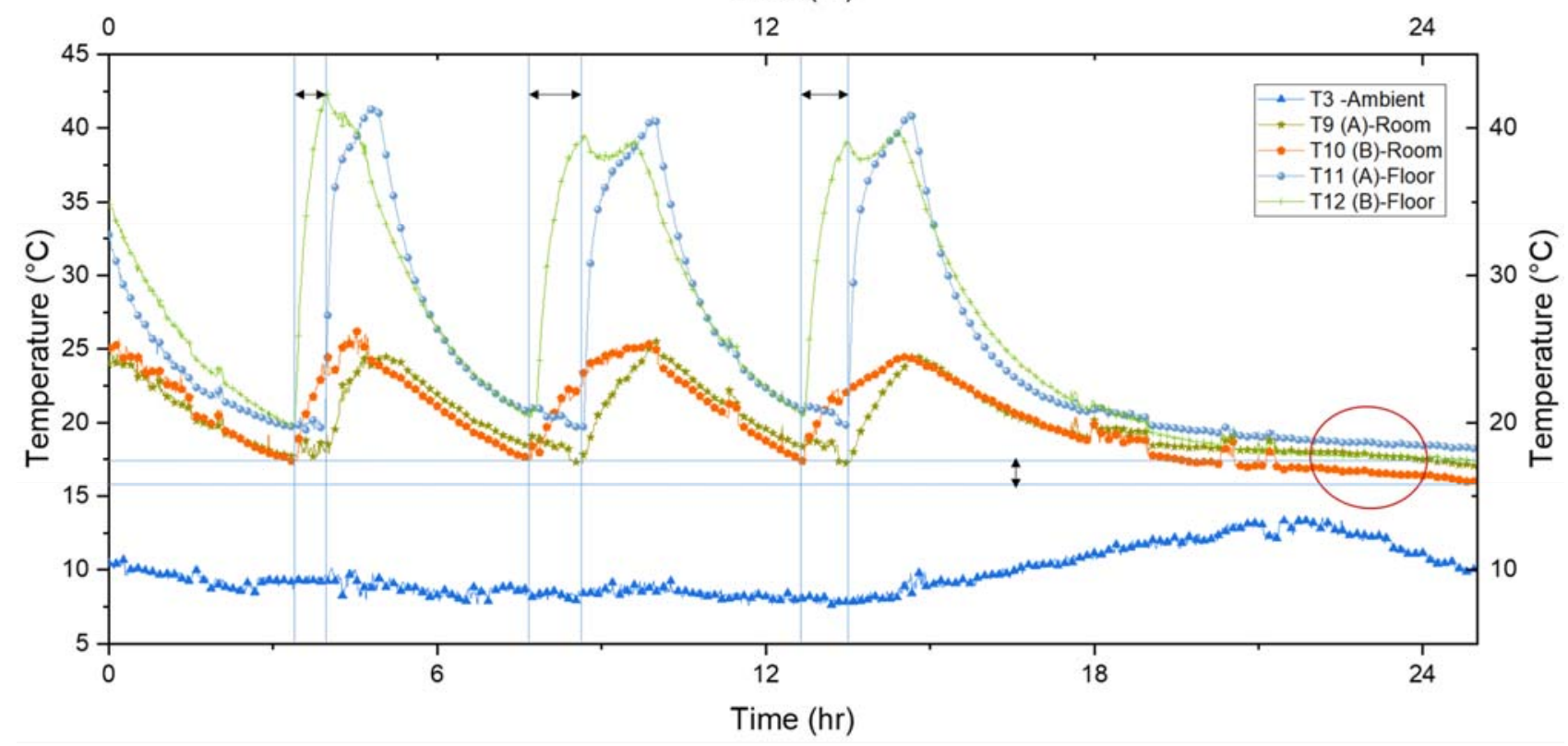

622 Figure 27 Variation of room temperature and floor surface temperatures for prototypes A and B of experiment 4 - stage 2. 


\section{3}

624

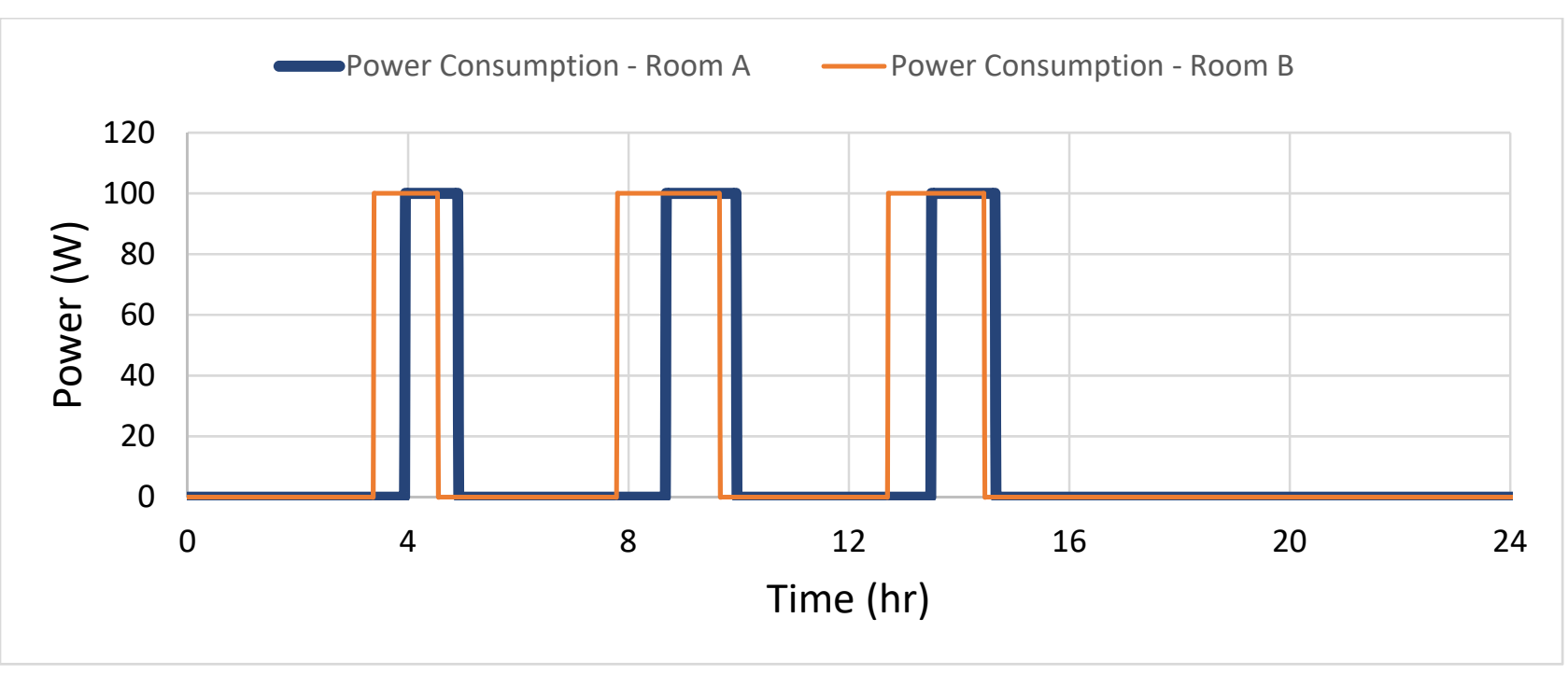

Figure 28 Pump power consumption for rooms $A$ and B during test 3

\section{Conclusions and Recommendations}

The current research was focused on studying the thermal performance of underfloor hydronic radiant heating system coupled with enhanced coconut oil PCM plates. Experimental aspect was followed, where four different experimental tests were done to: (1) investigate the effect of active CO-PCM coupled with variable weather conditions; (2) effect of combining active PCM system with passive PCM system; (3) effect of PCM type comparing CO-PCM with PW-PCM; and (4) the effect of PCM position, namely placing the PCM below HRFHS. The investigation utilized two identical small scale modular prototypes (ThermoGreen ${ }^{\circledR}$ ) with automated control systems for sustaining thermal comfort temperature range as for bounding heating and cooling phases within each test in each room. The study included thermal and economic analyses directed toward investigating the effects of PCM systems on achieving thermal comfort and reducing energy consumption and yearly operational costs. The major arising conclusions are:

1. The proposed modular design of the used prototype proved its capability to accommodate various parameters and their effect on thermal performance of the room.

2. Using CO-PCM filling enhanced thermal conductivity macro-containers within the layers of the tested prototypes is beneficial in terms of thermal comfort enhancement and annual cost savings.

3. Using CO-PCM as active application coupled to HRFHS, and when combined with passive wall and roof permit load shifting from high-peak to low-peak periods resulting in daily and annual cost savings.

4. Weather conditions alters the time zone (period) of heating operation which might lead to negative feedbacks regarding cost saving (experiment 1), where the operational cost of the control room is slightly less than that of PCM room.

5. The choice of PCM in the roof was not beneficial as the temperature of the roof did not reach the working temperature range of the PCM while maintain the room at $24{ }^{\circ} \mathrm{C}$.

6. PW-PCM proved to be more efficient than coconut oil in the case of using PCM as Active TES coupled to HFRHS although load shifting was attained by CO-PCM.

7. The position of PCM is very critical. Placing CO-PCM below HRFHS is more beneficial than placement above the heating system. This was obvious where experiment 4 proved the capability of PCM in achieving energy savings even if there were no electricity tariff shifts, unlike placing PCM above the PEX tubes that results in load shifting and requires differences in electricity costs at specific changeable time zones. 
8. Temperature fluctuation reductions leading to achieving residents' thermal comfort was attained by all cases utilizing PCM.

9. Using PCM is a key method toward environmental sustainability and reduction of greenhouse gases caused by heating and cooling conventional systems in residential buildings. It is a keyway toward changing renovations and new erections into NZEB.

As for future work, the following recommendations are suggested:

1. The study was focused on heating season and the effect of PCM on reducing heating annual operational costs, however using the system with additional features such as solar façade and nocturnal sky radiation coupled to the hydronic floor system is to be studied.

2. Economic and Environmental aspects are to be studied to surround the topic in more detail.

3. Combing PCM applications is favorable and requires that the choice of PCM for each system must comply with the other system. In the case of the current study PCM selection should follow the conventional uniform temperature distribution from the floor reaching the roof.

4. The skeletal frame of the prototype is recommended to be insulated from the envelope layers especially the underfloor heating layer as it represents a thermal bridge between envelope layers and indoor with outdoor, thus increasing losses.

5. The combination of triple systems: active HRFHS with passive envelope combined to active Trombe wall system is to be studied further on.

6. Thermally activated building structure utilizing CO-PCM in its envelope using capillary tubes and electric mats might be of favorable efficiency.

7. A simulation model using COMSOL Multiphysics can be beneficial in supporting optimization studies with ThermoGreen ${ }^{\circledR}$.

\section{References}

[1] F.S. Javadi, H.S.C. Metselaar, P. Ganesan, Performance improvement of solar thermal systems integrated with phase change materials (PCM), a review, Solar Energy. 206 (2020) 330-352. https://doi.org/10.1016/j.solener.2020.05.106.

[2] P. McKenna, W.J.N. Turner, D.P. Finn, Geocooling with integrated PCM thermal energy storage in a commercial building, Energy. 144 (2018) 865-876. https://doi.org/10.1016/j.energy.2017.12.029.

[3] M.T. Plytaria, C. Tzivanidis, E. Bellos, K.A. Antonopoulos, Energetic investigation of solar assisted heat pump under fl oor heating systems with and without phase change materials, Energy Conversion and Management. 173 (2018) 626-639. https://doi.org/10.1016/j.enconman.2018.08.010.

[4] A. Maccarini, G. Hultmark, N.C. Bergsøe, A. Afshari, Free cooling potential of a PCM-based heat exchanger coupled with a novel HVAC system for simultaneous heating and cooling of buildings, Sustainable Cities and Society. 42 (2018) 384-395. https://doi.org/10.1016/j.scs.2018.06.016.

[5] X. Kong, P. Jie, C. Yao, Y. Liu, Experimental study on thermal performance of phase change material passive and active combined using for building application in winter, Applied Energy. 206 (2017) 293302. https://doi.org/10.1016/j.apenergy.2017.08.176.

[6] J. Lizana, R. Chacartegui, A. Barrios-padura, C. Ortiz, Advanced low-carbon energy measures based on thermal energy storage in buildings: A review, Renewable and Sustainable Energy Reviews. 82 (2018) 3705-3749. https://doi.org/10.1016/j.rser.2017.10.093.

[7] K. Biswas, J. Lu, P. Soroushian, S. Shrestha, Combined experimental and numerical evaluation of a prototype nano-PCM enhanced wallboard q, Applied Energy. 131 (2014) 517-529. https://doi.org/10.1016/j.apenergy.2014.02.047.

[8] H.J. Alqallaf, E.M. Alawadhi, Concrete roof with cylindrical holes containing PCM to reduce the heat gain, Energy and Buildings. 61 (2013) 73-80. https://doi.org/10.1016/j.enbuild.2013.01.041.

[9] L. Karim, F. Barbeon, P. Gegout, A. Bontemps, L. Royon, New phase-change material components for thermal management of the light weight envelope of buildings, Energy and Buildings. 68 (2014) 703706. https://doi.org/10.1016/j.enbuild.2013.08.056. 
[10] A. Kasaeian, L. bahrami, F. Pourfayaz, E. Khodabandeh, W.M. Yan, Experimental studies on the applications of PCMs and nano-PCMs in buildings: A critical review, Energy and Buildings. 154 (2017) 96-112. https://doi.org/10.1016/j.enbuild.2017.08.037.

[11] K. Du, J. Calautit, Z. Wang, Y. Wu, H. Liu, A review of the applications of phase change materials in cooling, heating and power generation in different temperature ranges, Applied Energy. 220 (2018) 242273. https://doi.org/10.1016/j.apenergy.2018.03.005.

[12] J. Lee, S. Wi, S. Yang, S. Kim, Experimental study and assessment of high-tech thermal energy storing radiant floor heating system with latent heat storage materials, International Journal of Thermal Sciences. 155 (2020). https://doi.org/10.1016/j.ijthermalsci.2020.106410.

[13] M. Mofijur, T. Meurah, I. Mahlia, A.S. Silitonga, H.C. Ong, M. Silakhori, M.H. Hasan, N. Putra, S.M.A. Rahman, Phase Change Materials (PCM) for Solar Energy Usages and Storage: An Overview, Energies. 12 (2019) 1-20. https://doi.org/10.3390/en12163167.

[14] N. Zhu, N. Hu, P. Hu, F. Lei, S. Li, Experiment study on thermal performance of building integrated with double layers shape-stabilized phase change material wallboard, Energy. (2018). https://doi.org/10.1016/j.energy.2018.11.042.

[15] N. Zhu, M. Wu, P. Hu, L. Xu, F. Lei, S. Li, Performance study on different location of double layers SSPCM wallboard in office building, Energy \& Buildings. 158 (2018) 23-31. https://doi.org/10.1016/j.enbuild.2017.09.075.

[16] R.J. Khan, Z.H. Bhuiyan, D.H. Ahmed, Investigation of heat transfer of a building wall in the presence of phase change material (PCM), Energy and Built Environment. 1 (2020) 199-206. https://doi.org/https://doi.org/10.1016/j.enbenv.2020.01.002.

[17] A.A. Abed, O.K. Ahmed, M.M. Weis, K.I. Hamada, Performance augmentation of a PV/Trombe wall using A12O3/Water nano-fluid: An experimental investigation, Renewable Energy. 157 (2020) 515-529. https://doi.org/10.1016/j.renene.2020.05.052.

[18] A. De Gracia, L. Navarro, A. Castell, Á. Ruiz-pardo, Solar absorption in a ventilated facade with PCM . Experimental results, 30 (2012) 986-994. https://doi.org/10.1016/j.egypro.2012.11.111.

[19] A. de Gracia, L. Navarro, A. Castell, L.F. Cabeza, Energy performance of a ventilated double skin facade with PCM under different climates, Energy and Buildings. 91 (2015) 37-42. https://doi.org/10.1016/j.enbuild.2015.01.011.

[20] T.A. Vik, H.B. Madessa, P. Aslaksrud, E. Folkedal, O.S. Øvrevik, Thermal Performance of an Office Cubicle Integrated with a Bio-based PCM: Experimental Analyses, Energy Procedia. 111 (2017) 609618. https://doi.org/10.1016/j.egypro.2017.03.223.

[21] D. Li, Y. Wu, C. Liu, G. Zhang, M. Arıc1, Numerical investigation of thermal and optical performance of window units filled with nanoparticle enhanced PCM, International Journal of Heat and Mass Transfer. 125 (2018) 1321-1332. https://doi.org/10.1016/j.ijheatmasstransfer.2018.04.152.

[22] N. Sarier, E. Onder, Organic phase change materials and their textile applications: An overview, Thermochimica Acta. 540 (2012) 7-60. https://doi.org/10.1016/j.tca.2012.04.013.

[23] H. Johra, P. Heiselberg, Influence of internal thermal mass on the indoor thermal dynamics and integration of phase change materials in furniture for building energy storage: A review, Renewable and Sustainable Energy Reviews. 69 (2017) 19-32. https://doi.org/10.1016/j.rser.2016.11.145.

[24] B.Y. Yun, J.H. Park, S. Yang, S. Wi, S. Kim, Integrated analysis of the energy and economic efficiency of PCM as an indoor decoration element: Application to an apartment building, Solar Energy. 196 (2020) 437-447. https://doi.org/10.1016/j.solener.2019.12.006.

[25] R. Barzin, J.J.J. Chen, B.R. Young, M.M. Farid, Application of PCM underfloor heating in combination with PCM wallboards for space heating using price based control system, Applied Energy. 148 (2015) 39-48. https://doi.org/10.1016/j.apenergy.2015.03.027.

[26] K. Faraj, J. Faraj, F. Hachem, H. Bazzi, M. Khaled, C. Castelain, Analysis of underfloor electrical heating system integrated with coconut oil-PCM plates, Applied Thermal Engineering. 158 (2019). https://doi.org/10.1016/j.applthermaleng.2019.113778.

[27] P. Devaux, M.M. Farid, Benefits of PCM underfloor heating with PCM wallboards for space heating in winter, Applied Energy. 191 (2017) 593-602. https://doi.org/10.1016/j.apenergy.2017.01.060.

[28] T. Bouhal, T.E. Rhafiki, T. Kousksou, A. Jamil, Y. Zeraouli, PCM addition inside solar water heaters : Numerical comparative approach, Journal of Energy Storage. 19 (2018) 232-246. https://doi.org/10.1016/j.est.2018.08.005. 
[29] W. He, C. Yu, J. Yang, B. Yu, Z. Hu, D. Shen, X. Liu, M. Qin, H. Chen, Experimental study on the performance of a novel RC-PCM-wall, Energy and Buildings. 199 (2019) 297-310. https://doi.org/10.1016/j.enbuild.2019.07.001.

[30] M. Abuşka, S. Şevik, A. Kayapunar, A comparative investigation of the effect of honeycomb core on the latent heat storage with PCM in solar air heater, Applied Thermal Engineering. (2018). https://doi.org/10.1016/j.applthermaleng.2018.11.056.

[31] A. Wadhawan, A.S. Dhoble, V.B. Gawande, Analysis of the effects of use of thermal energy storage device ( TESD ) in solar air heater, Alexandria Engineering Journal. (2017). https://doi.org/10.1016/j.aej.2017.03.016.

[32] C.Q. Chen, Y.H. Diao, Y.H. Zhao, Z.Y. Wang, L. Liang, T.Y. Wang, T.T. Zhu, C. Ma, Thermal performance of a closed collector-storage solar air heating system with latent thermal storage: An experimental study, Energy. 202 (2020). https://doi.org/10.1016/j.energy.2020.117764.

[33] K. Faraj, M. Khaled, J. Faraj, F. Hachem, C. Castelain, A review on phase change materials for thermal energy storage in buildings: Heating and hybrid applications, Journal of Energy Storage. (2020). https://doi.org/10.1016/j.est.2020.101913.

[34] K. Faraj, M. Khaled, J. Faraj, F. Hachem, C. Castelain, Phase change material thermal energy storage systems for cooling applications in buildings: A review, Renewable and Sustainable Energy Reviews. (2019). https://doi.org/10.1016/j.rser.2019.109579.

[35] K. Lin, Y. Zhang, X. Xu, H. Di, Experimental study of under-floor electric heating system with shapestabilized PCM plates, Energy and Buildings. 37 (2005) 215-220. https://doi.org/10.1016/j.enbuild.2004.06.017.

[36] K. Lin, Y. Zhang, X. Xu, H. Di, R. Yang, P. Qin, Modeling and simulation of under- oor electric heating system with shape-stabilized PCM plates, 39 (2004) 1427-1434. https://doi.org/10.1016/j.buildenv.2004.04.005.

[37] K. Huang, G. Feng, J. Zhang, Experimental and numerical study on phase change material floor in solar water heating system with a new design, Solar Energy. 105 (2014) 126-138. https://doi.org/10.1016/j.solener.2014.03.009.

[38] W. Cheng, B. Xie, R. Zhang, Z. Xu, Y. Xia, Effect of thermal conductivities of shape stabilized PCM on under-floor heating system, APPLIED ENERGY. 144 (2015) 10-18. https://doi.org/10.1016/j.apenergy.2015.01.055.

[39] G. Zhou, J. He, Thermal performance of a radiant floor heating system with different heat storage materials and heating pipes, Applied Energy. 138 (2015) 648-660. https://doi.org/10.1016/j.apenergy.2014.10.058.

[40] Y. Zhou, S. Zheng, H. Chen, G. Zhang, Indoor and Built Thermal performance and optimized thickness of active shape-stabilized PCM boards for side-wall cooling and under-floor heating system, Indoor and Built Environment. 25 (2016) 1279-1295. https://doi.org/10.1177/1420326X16671983.

[41] S. Lu, Y. Zhao, K. Fang, Y. Li, P. Sun, Establishment and experimental verification of TRNSYS model for PCM floor coupled with solar water heating system, Energy \& Buildings. 140 (2017) 245-260. https://doi.org/10.1016/j.enbuild.2017.02.018.

[42] H. Garg, B. Pandey, S.K. Saha, S. Singh, R. Banerjee, Design and analysis of PCM based radiant heat exchanger for thermal management of buildings, Energy and Buildings. 169 (2018) 84-96. https://doi.org/10.1016/j.enbuild.2018.03.058.

[43] M. Jobli, R. Yao, Z. Luo, M. Shahrestani, N. Li, L. Hong, Numerical and experimental studies of a Capillary-Tube embedded PCM component for improving indoor thermal environment, Applied Thermal Engineering. 148 (2019) 466-477. https://doi.org/10.1016/j.applthermaleng.2018.10.041.

[44] Y. Fang, Y. Ding, Y. Tang, X. Liang, C. Jin, S. Wang, X. Gao, Thermal properties enhancement and application of a novel sodium acetate trihydrate-formamide/expanded graphite shape-stabilized composite phase change material for electric radiant floor heating, Applied Thermal Engineering. 150 (2019) 1177-1185. https://doi.org/10.1016/j.applthermaleng.2019.01.069.

[45] S. Lu, H. Tong, B. Pang, Study on the coupling heating system of floor radiation and sunspace based on energy storage technology, Energy and Buildings. 159 (2018) 441-453. https://doi.org/10.1016/j.enbuild.2017.11.027.

[46] L. Zhu, Y. Yang, Numerical study on the thermal performance of pipe-embedded PCM building envelope in the heating season, Energy Procedia. 158 (2019) 2663-2670. 
[47] M.T. Plytaria, E. Bellos, C. Tzivanidis, K.A. Antonopoulos, Numerical simulation of a solar cooling system with and without phase change materials in radiant walls of a building, Energy Conversion and Management. 188 (2019) 40-53. https://doi.org/10.1016/j.enconman.2019.03.042.

[48] M.T. Plytaria, C. Tzivanidis, E. Bellos, K.A. Antonopoulos, Parametric analysis and optimization of an under floor solar assisted heating system with phase change materials, Thermal Science and Engineering Progress. 10 (2019) 59-72. https://doi.org/10.1016/j.tsep.2019.01.010.

[49] W. Sun, Y. Zhang, Z. Ling, X. Fang, Z. Zhang, Experimental investigation on the thermal performance of double-layer PCM radiant floor system containing two types of inorganic composite PCMs, Energy and Buildings. 211 (2020). https://doi.org/10.1016/j.enbuild.2020.109806.

[50] PhaseChange, Technical Data - Q29, BioPCM Q29. (n.d.). https://phasechange.com/wpcontent/uploads/2018/02/BioPCM-Data-Sheet-Q29.pdf.

[51] W. Fu, T. Zou, X. Liang, S. Wang, X. Gao, Z. Zhang, Preparation and properties of phase change temperature-tuned composite phase change material based on sodium acetate trihydrate-urea/fumed silica for radiant floor heating system, Applied Thermal Engineering. 162 (2019). https://doi.org/10.1016/j.applthermaleng.2019.114253.

[52] H.D. Young, Values for diamond and silica aerogel from CRC Handbook of Chemistry and Physics, University Physics. (n.d.). http://hyperphysics.phy-astr.gsu.edu/hbase/Tables/thren.html.

[53] Thermtest, COMMON MATERIAL THERMAL PROPERTIES, (2019). https://thermtest.com/materials-database.

[54] Owens-corning, Foamular Extruded Plystyrene (XPS) Insulation: SI and IP units for selected properties, (2011). https://dcpd6wotaa0mb.cloudfront.net/mdms/dms/EIS/10015703/10015703-FOAMULAR-SIand-I-P-Units-for-Selected-Properties-Tech.-Bulletin.pdf.

[55] G. Hammond, C. Jones, Enventory of Carbon and Energy, 2nd ed., Elsevier, 2011. https://www.sciencedirect.com/topics/engineering/insulation-material.

[56] Engineering Toolbox, Specific Heat of some common Substances, (2003). https://www.engineeringtoolbox.com/specific-heat-capacity-d_391.html (accessed September 30, 2020).

[57] J.D. Maclean, W. Madison, Thermal Conductivity of Wood, Heatig, Piping and Air Conditioning. 13 (1941) 380-391. https://www.fpl.fs.fed.us/documnts/pdf1941/macle41a.pdf.

[58] 3A Composites, ALUCOBOND technical data, (2020). https://alucobond.com.sg/products/alucobond/technical-data/.

[59] F. McQuiston, J. Parker, J. Spitler, Heating, Ventilating and Air Conditioning Analysis and Design, 6th editio, John Wiley \& Sons, Inc., 2005.

[60] N. Ukrainczyk, S. Kurajica, J. Sipusic, Thermophysical Comparison of Five Commercial Paraffin Waxes as Latent Heat Storage Materials, Chemical and Biochemical Engineering Quarterly. 24 (2010) 129-137. https://doi.org/10.15255/CABEQ.2014.240.

[61] E.S. Mettawee, A.I. Ead, Energy Saving in Building with Latent Heat Storage, International Journal of Thermal and Environmental Engineering. 5 (2013) 21-30. https://doi.org/10.5383/ijtee.05.01.003.

[62] S. Wonorahardjo, I.M. Sutjahja, D. Kurnia, Z. Fahmi, W.A. Putri, Potential of Thermal Energy Storage Using Coconut Oil for Air Temperature Control, Buildings. 2 (2018). https://doi.org/10.3390/buildings8080095.

[63] H. Lee, S. Jeong, S.J. Chang, Y. Kang, S. Wi, S. Kim, Thermal Performance Evaluation of Fatty Acid Ester and Paraffin Based Mixed SSPCMs Using Exfoliated Graphite Nanoplatelets (xGnP), Applied Sciences. 6 (2016) 106. https://doi.org/10.3390/app6040106.

[64] W.A. Putri, Z. Fahmi, I.M. Sutjahja, D. Kurnia, S. Wonorahardjo, Thermophysical parameters of coconut oil and its potential application as the thermal energy storage system in Indonesia, Journal of Physics: Conference Series. 739 (2016). https://doi.org/10.1088/1742-6596/739/1/012065.

[65] M. Irsyad, Harmen, Heat transfer characteristics of coconut oil as phase change material to room cooling application, in: 1st International Symposium on Green Technology for Value Chains 2016, IOP Conference Series: Earth and Environmental Science 60, 2017. https://doi.org/10.1088/1755-1315/.

[66] P.V. Krishna, R.R. Srikant, D.N. Rao, Experimental investigation on the performance of nanoboric acid suspensions in SAE-40 and coconut oil during turning of AISI 1040 steel, International Journal of Machine Tools and Manufacture. 50 (2010) 911-916. https://doi.org/10.1016/j.ijmachtools.2010.06.001.

[67] N. Putra, S. Rawi, M. Amin, E. Kusrini, E.A. Kosasih, T.M.I. Mahlia, Preparation of beeswax/multi- 
walled carbon nanotubes as novel shape-stable nanocomposite phase change material for thermal energy storage, Journal of Energy Storage. 21 (2019) 32-39. https://doi.org/10.1016/j.est.2018.11.007.

[68] M. Amin, N. Putra, E.A. Kosasih, E. Prawiro, R.A. Luanto, T.M.I. Mahlia, Thermal properties of beeswax/graphene phase change material as energy stor- age for building applications, Applied Thermal Engineering. 112 (2016) 273-280. https://doi.org/10.1016/j.applthermaleng.2016.10.085.

[69] M. Mehrali, S. Tahan, M. Mehrali, T. Meurah, I. Mahlia, H. Simon, C. Metselaar, M. Sajad, E. Sadeghinezhad, A. Reza, Preparation and characterization of palmitic acid/graphene nanoplatelets composite with remarkable thermal conductivity as a novel shape-stabilized phase change material, Applied Thermal Engineering. 61 (2013) 633-640. https://doi.org/10.1016/j.applthermaleng.2013.08.035.

[70] S.T. Latibari, M. Mehrali, M. Mehrali, T.M.I. Mahlia, H.S.C. Metselaar, Synthesis, characterization and thermal properties of nanoencapsulated phase change materials via sol-gel method, Energy. 61 (2013) 664-672. https://doi.org/10.1016/j.energy.2013.09.012.

[71] Plastics Pipe Institute, PEX-ALUMINUM-PEX COMPOSITE (PEX-AL-PEX), (2020). https://plasticpipe.org/building-construction/bcd-pex-al-pex.html (accessed May 23, 2021).

[72] Eurachem, CITAC, Quantifying Uncertainty in Analytical Measurement, Third, Eurachem / CITAC Guide CG 4, 2012.

[73] D. Shen, C. Yu, W. Wang, Investigation on the thermal performance of the novel phase change materials wall with radiative cooling, Applied Thermal Engineering. 176 (2020). https://doi.org/10.1016/j.applthermaleng.2020.115479.

[74] B.P. Jelle, S.E. Kalnæs, Phase Change Materials for Application in Energy-Efficient Buildings, Elsevier Ltd, 2017. https://doi.org/10.1016/B978-0-08-101128-7.00003-4.

[75] Y. Li, J. Zhou, E. Long, X. Meng, Experimental study on thermal performance improvement of building envelopes by integrating with phase change material in an intermittently heated room, Sustainable Cities and Society. (2018). https://doi.org/10.1016/j.scs.2018.01.040.

[76] S. Wijesuriya, M. Brandt, P.C. Tabares-velasco, Parametric analysis of a residential building with phase change material ( PCM ) -enhanced drywall, precooling, and variable electric rates in a hot and dry climate Time of Use, Applied Energy. 222 (2018) 497-514. https://doi.org/10.1016/j.apenergy.2018.03.119.

[77] F. Mehdaoui, M. Hazami, A. Messaouda, H. Taghouti, A. Guizani, Thermal testing and numerical simulation of PCM wall integrated inside a test cell on a small scale and subjected to the thermal stresses, Renewable Energy. (2018). https://doi.org/10.1016/j.renene.2018.12.029. 